\title{
Regulation of neurosteroid biosynthesis by neurotransmitters and neuropeptides
}

\author{
Jean Luc Do Rego ${ }^{1,2,3}$, Jae Young Seong ${ }^{4}$, Delphine Burel ${ }^{1,2,3,5}$, Jerôme Leprince ${ }^{1,2,3,5}$, David Vaudry ${ }^{1,2,3,5}$, \\ Van Luu-The ${ }^{6}$, Marie-Christine Tonon ${ }^{1,2,3,5}$, Kazuyoshi Tsutsui ${ }^{7,8}$, Georges Pelletier ${ }^{6}$ and Hubert Vaudry ${ }^{1,2,3,5 *}$ \\ 1 INSERM, Mont-Saint-Aignan, France \\ ${ }^{2}$ European Institute for Peptide Research, IFRMP 23, Regional Platform for Cell Imaging, PRIMACEN, University of Rouen, Mont-Saint-Aignan, France \\ 3 International Associated Laboratory Samuel de Champlain, Mont-Saint-Aignan, France \\ ${ }^{4}$ Laboratory of G Protein-Coupled Receptors, Graduate School of Medicine, Korea University College of Medicine, Seoul, Korea \\ ${ }^{5}$ Laboratory of Neuronal and Neuroendocrine Differentiation and Communication, INSERM U982, University of Rouen, Mont-Saint-Aignan, France \\ ${ }^{6}$ Research Center in Molecular Endocrinology, Oncology and Genetics, Laval University Hospital Center, Québec, QC, Canada \\ 7 Laboratory of Integrative Brain Sciences, Department of Biology, Waseda University, Tokyo, Japan \\ ${ }^{8}$ Center for Medical Life Science of Waseda University, Tokyo, Japan
}

Edited by:

Olivier Kah, CNRS UMR 6026, France

\section{Reviewed by:}

Gustavo M. Somoza, Instituto de Investigaciones

Biotecnologicas-Instituto Tecnologico

de Chascomus, Argentina

James A. Carr, Texas Tech University, USA

\section{*Correspondence:}

Hubert Vaudry, INSERM U982,

European Institute for Peptide

Research, IFRMP 23, University of

Rouen, 76821 Mont-Saint-Aignan,

France.

e-mail: hubert.vaudry@univ-rouen.fr
The enzymatic pathways leading to the synthesis of bioactive steroids in the brain are now almost completely elucidated in various groups of vertebrates and, during the last decade, the neuronal mechanisms involved in the regulation of neurosteroid production have received increasing attention. This report reviews the current knowledge concerning the effects of neurotransmitters, peptide hormones, and neuropeptides on the biosynthesis of neurosteroids. Anatomical studies have been carried out to visualize the neurotransmitteror neuropeptide-containing fibers contacting steroid-synthesizing neurons as well as the neurotransmitter, peptide hormones, or neuropeptide receptors expressed in these neurons. Biochemical experiments have been conducted to investigate the effects of neurotransmitters, peptide hormones, or neuropeptides on neurosteroid biosynthesis, and to characterize the type of receptors involved. Thus, it has been found that glutamate, acting through kainate and/or AMPA receptors, rapidly inactivates P450arom, and that melatonin produced by the pineal gland and eye inhibits the biosynthesis of $7 \alpha$-hydroxypregnenolone $\left(7 \alpha-\mathrm{OH}-\Delta^{5} \mathrm{P}\right)$, while prolactin produced by the adenohypophysis enhances the formation of $7 \alpha-\mathrm{OH}-\Delta^{5} \mathrm{P}$. It has also been demonstrated that the biosynthesis of neurosteroids is inhibited by GABA, acting through $\mathrm{GABA}_{A}$ receptors, and neuropeptide $\mathrm{Y}$, acting through Y1 receptors. In contrast, it has been shown that the octadecaneuropetide ODN, acting through central-type benzodiazepine receptors, the triakontatetraneuropeptide TTN, acting though peripheral-type benzodiazepine receptors, and vasotocin, acting through V1a-like receptors, stimulate the production of neurosteroids. Since neurosteroids are implicated in the control of various neurophysiological and behavioral processes, these data suggest that some of the neurophysiological effects exerted by neurotransmitters and neuropeptides may be mediated via the regulation of neurosteroid production.

Keywords: neurosteroids, glutamate, GABA, melatonin, prolactin, endozepines, vasopressin, neuropeptide Y

\section{INTRODUCTION}

The regulatory effects of steroid hormones in the central nervous system (CNS) have long been recognized (McEwen, 1994; Baulieu et al., 1999; Dubrovsky, 2005; Leskiewicz et al., 2006). Steroids acting on the CNS originate from two sources: (1) steroids produced by peripheral endocrine glands, i.e., gonads, adrenal, and placenta, that have to cross the blood-brain barrier to act on the brain, are usually designated as neuroactive steroids; (2) steroids directly synthesized within the CNS, either de novo from cholesterol or by in situ metabolism of circulating steroid precursors, are designated by the generic term neurosteroids (Robel and Baulieu, 1985, 1994; Baulieu, 1997, 1998). The capability of the nervous system to synthesize steroids was originally discovered in mammals (Corpéchot et al., 1981, 1983; Lanthier and Patwardhan, 1986) and was subsequently generalized in other vertebrates including birds, amphibians, and fish (Mensah-Nyagan et al., 1999; Mellon and Vaudry, 2001; Tsutsui et al., 2003, 2009; Do Rego et al., 2009; Diotel et al., 2010) indicating that de novo neurosteroidogenesis is a conserved property in the vertebrate phylum.

There is growing evidence that neurosteroids play an important role as endogenous modulators of neuronal functions and behavioral processes, and that alterations of neurosteroid concentrations may contribute to the pathophysiology of neuronal disorders (Majewska, 1992; Robel et al., 1999; Rupprecht and Holsboer, 1999; Lapchak et al., 2000; Lapchak and Araujo, 2001; Rupprecht et al., 2001; Dubrovsky, 2005; Belelli et al., 2006; Strous et al., 2006). For instance, in rat, infusion of pregnenolone sulfate $\left(\Delta^{5} \mathrm{PS}\right)$ and dehydroepiandrosterone sulfate (DHEAS) into 
the nucleus basalis magnocellularis enhances learning and memory (Mayo et al., 1993; Robel et al., 1995). Reciprocally, deficit in cognitive performances in aged rats and mice is correlated with low $\Delta^{5}$ PS and DHEAS levels in the hippocampus (Flood et al., 1988, 1992; Vallée et al., 1997, 2001; Ladurelle et al., 2000). In chickens, administration of DHEA and DHEAS enhances learning and memory (Migues et al., 2002). In humans, DHEA and DHEAS are considered to play a role in memory both in normal subjects and aging patients (Sunderland et al., 1989; Nasman et al., 1991; Strous et al., 2006). More specifically, with regards to Alzheimer's disease, decreased levels of several neurosteroids have been observed in the frontal cortex, hippocampus, amygdala, striatum, hypothalamus, and cerebellum (Sunderland et al., 1989; Nasman et al., 1991; Weill-Engerer et al., 2002; Schumacher et al., 2003). The best known role of neurosteroids is their involvement in the control of mood disorders. Numerous behavioral investigations have shown that neurosteroids exert anxiolytic (Hodge et al., 2002; Strous et al., 2003), anti-depressant (Uzunova et al., 2003; van Broekhoven and Verkes, 2003), anti-aggressive (Kavaliers and Kinsella, 1995; Pinna et al., 2008), hypnotic (Lancel et al., 1997; Damianisch et al., 2001), anti-convulsive (Landgren et al., 1987; Belelli et al., 1989), and anti-stress actions (Patchev et al., 1996; Hu et al., 2000). In animal models, an effect of neurosteroids in eating disorders has been reported (Reddy and Kulkarni, 1998, 1999; Strous et al., 2006). In particular, DHEA decreases food intake (Svec and Porter, 1996; Svec et al., 1998), reduces insulin resistance (Svec and Porter, 1998a,b), and lowers adiposity (Svec and Porter, 1998a,b; Pham et al., 2000). DHEAS has also been found to induce a significant decrease in food intake and body weight (Reddy and Kulkarni, 1999; Kaur and Kulkarni, 2001). In contrast, allopregnanolone causes hyperphagia in male and female rats (Reddy and Kulkarni, 1999). The dose-dependent effects of $\Delta^{5} \mathrm{PS}$ on locomotion of mice placed in a novel environment show the existence of a possible role of neurosteroids in adaptation to novelty (Fahey et al., 1995a). Neurosteroids are also involved in the regulation of excitotoxic and apoptotic processes (Kimonides et al., 1999; Frank and Sagratella, 2000; Manji et al., 2003; Charalampopoulos et al., 2004; Wojtal et al., 2006). In vivo studies indicate that progesterone, allopregnanolone, and DHEA exert neuroprotective effects in models of traumatic brain injury (Stein, 2001; Malik et al., 2003; Djebaili et al., 2004; He et al., 2004) and in focal cerebral ischemia (Malik et al., 2003; Sayeed et al., 2006). In vitro data also point to the neuroprotective effects of neurosteroids in models of neuronal injury against neurotoxic insults inflicted by excitatory amino acids (Kimonides et al., 1999; Gursoy et al., 2001) and $\beta$-amyloid peptides (Kimonides et al., 1998, 1999; Frank and Sagratella, 2000; Lockhart et al., 2002; Xilouri and Papazafiri, 2006). It has been demonstrated that neurosteroids play important functions in neurodevelopment and neuronal remodeling, including neurogenesis (Roberts, 1986; Weaver et al., 1997; Schumacher et al., 2000; Magnaghi et al., 2001; Young, 2002), axonal and dendritic growth, and synaptic connectivity (Jones, 1994; Compagnone and Mellon, 1998). In addition to their protective effects on the brain, neurosteroids can regulate myelin formation and increase expression of myelin proteins in the sciatic nerve (Koenig et al., 1995; Murakami et al., 2000; Plassart-Schiess and Baulieu,
2001; Laurine et al., 2003; Melcangi et al., 2003; Iwata et al., 2005).

The effects of neurosteroids on neuronal activity are mediated through several distinct categories of receptors. Neurosteroids, like other steroid hormones, can act at the transcriptional level through interaction with nuclear receptors (McEwen, 1994; Rupprecht, 1997; Mo et al., 2004). Neurosteroids may also interact with plasma membrane $\mathrm{G}$ protein-coupled receptors either directly (Schiess and Partridge, 2005; Tasker et al., 2006) or indirectly by modulating the binding of neuropeptides to their receptors (Grazzini et al., 1998; Zwain et al., 2002; Torres and Ortega, 2003). In addition, neurosteroids can stimulate tubulin polymerization in cultured neurons by binding to the microtubule-associated protein-2 (Murakami et al., 2000; Plassart-Schiess and Baulieu, 2001; Laurine et al., 2003; Iwata et al., 2005). However, most of the actions of neurosteroids are mediated via allosteric modulation of neurotransmitter receptors, including the $\mathrm{GABA}_{\mathrm{A}} /$ central-type benzodiazepine receptor (CBR) complex (Belelli and Lambert, 2005; Belelli et al., 2006; Zheng, 2009), N-methyl-D-aspartate (NMDA; Mameli et al., 2005; Monnet and Maurice, 2006), kainate (Costa et al., 2000; Dubrovsky, 2005), $\alpha$-amino-3-hydroxy-5methyl-4-isoxazole-propionic acid (AMPA; Rupprecht and Holsboer, 2001; Dubrovsky, 2005), glycine (Jiang et al., 2006; Mitchell et al., 2007), sigma (Monnet et al., 1995; Maurice et al., 2006), serotonergic (Kostowski and Bienkowski, 1999; Shannon et al., 2005a,b), nicotinic (Valera et al., 1992; Bullock et al., 1997), and muscarinic receptors (Horishita et al., 2005; Steffensen et al., 2006). For example, the effects of GABA on the $\mathrm{GABA}_{\mathrm{A}}$ receptor are allosterically potentiated by progesterone and deoxycorticosterone metabolites such as allopregnanolone, pregnanolone, and tetrahydrodeoxycorticosterone (Majewska et al., 1986; Majewska, 1992; Paul and Purdy, 1992; Bergeron et al., 1996). On the other hand, $\triangle^{5} \mathrm{PS}$ and DHEA have been reported to inhibit $\mathrm{GABA}_{\mathrm{A}}$ receptor activity (Majewska and Schwartz, 1987; Park-Chung et al., 1999). Allopregnanolone is a negative modulator of the NMDA receptors (Wu et al., 1991; Bowlby, 1993). In contrast, $\Delta^{5} \mathrm{PS}$ and DHEA potentiate several NMDA-receptor-mediated responses, and thus act as excitatory neurosteroids (Wu et al., 1991; Irwin et al., 1992; Fahey et al., 1995b; Compagnone and Mellon, 1998). At the AMPA and kainate receptors, $\Delta^{5} \mathrm{PS}$ behaves as a negative modulator (Rupprecht, 1997; Mellon and Griffin, 2002). It has also been demonstrated that DHEAS acts as a sigma receptor agonist, $\Delta^{5} \mathrm{PS}$ as a sigma receptor inverse agonist, and progesterone as a sigma receptor antagonist (Monnet et al., 1995).

The biochemical pathways leading to the synthesis of steroids in the nervous system of vertebrates have now been almost completely elucidated (Tsutsui and Yamazaki, 1995; Tsutsui et al., 1999; Compagnone and Mellon, 2000; Do Rego et al., 2009; Diotel et al., 2011; Vaudry et al., 2011) and it is now firmly established that neurosteroids regulate neuronal activity (Reddy, 2003, 2010; Dubrovsky, 2005; Belelli et al., 2006; Strous et al., 2006). Over the last decade, a number of studies have thus been undertaken to decipher the neuronal mechanisms involved in the regulation of neurosteroid production. In the present report, we review the current knowledge regarding the effects and mode of action of neurotransmitters, peptide hormones, and neuropeptides on the 
biosynthesis of neurosteroids in the CNS of vertebrates. Remarkably, most of these studies have been conducted in the brain of amphibians and birds. In fact, since the rate of steroid synthesis is relatively high in the CNS of frog, quail, and zebra finch (MensahNyagan et al., 1994, 1996; Tsutsui et al., 2006, 2009; Do Rego et al., 2007a; Schlinger and Remage-Healey, 2011), these animals have proved to be suitable models in which to investigate the neuronal mechanisms regulating neurosteroid production.

\section{EFFECT OF GLUTAMATE ON NEUROSTEROID BIOSYNTHESIS}

In the quail forebrain, all classes of ionotropic glutamate receptors, i.e., NMDA, AMPA, and kainate receptors, are expressed in the medial preoptic nucleus, a region which is enriched with P450arom-containing cell bodies (Cornil et al., 2000), suggesting that these neurons may be regulated by glutamate. Consistent with this hypothesis, incubation of quail hypothalamic fragments with AMPA and kainate, and to a certain extent NMDA, inhibits P450arom activity (Balthazart et al., 2001a). In mice, administration of NMDA or glutamate within the nidopallium provokes a substantial decrease in the local concentration of estradiol (Remage-Healey et al., 2008; Cornil, 2009). These observations indicate that, in birds and mammals, glutamate exerts an inhibitory action on the formation of neuroestrogens. In the quail brain, the inhibitory effects of AMPA and kainate are mimicked by ATP, $\mathrm{Ca}^{2+}$ and $\mathrm{Mg}^{2+}$, and the $\mathrm{Ca}^{2+}$ response is abrogated by PKA, PKC, and CAMK (Balthazart et al., 2001b, 2003). Since P450arom possesses several concensus phosphorylation sites in its sequence (Harada, 1988; Balthazart et al., 2003), it appears that the rapid inhibitory effect of AMPA, kainate, or NMDA on P450arom activity can be ascribed to $\mathrm{Ca}^{2+}$-dependent phosphorylation of the P450arom protein (Balthazart et al., 2001c, 2003).

\section{EFFECT OF MELATONIN ON NEUROSTEROID BIOSYNTHESIS}

Measurement of neurosteroid content and/or biosynthesis in the brain of vertebrates has revealed that marked changes in $\Delta^{5} \mathrm{P}$, $7 \alpha$-hydroxypregnenolone $\left(7 \alpha-\mathrm{OH}-\Delta^{5} \mathrm{P}\right), \mathrm{P}, \mathrm{THP}$, and $\Delta^{5} \mathrm{PS}$ occur during circadian and seasonal cycles (Jo et al., 1990; Takase et al., 1999; Inai et al., 2003; Matsunaga et al., 2004; Tsutsui et al., 2008). These changes often parallel or mirror variations in plasma melatonin concentrations (Hau and Gwinner, 1994; Warren and Cassone, 1995; Marumoto et al., 1996; Murakami et al., 2001). It has been shown that melatonin regulates locomotor activity in house sparrow, Japanese quail, red-bellied newt, ural owl, rock pigeon, and Sprague Dawley rat (Hau and Gwinner, 1994; Warren and Cassone, 1995; Murakami et al., 2001). $7 \alpha-\mathrm{OH}-\Delta^{5} \mathrm{P}$, in very much the same as melatonin, regulates locomotor activity in Japanese quail and red-bellied newt (Matsunaga et al., 2004; Tsutsui et al., 2008), suggesting that melatonin may control $7 \alpha-\mathrm{OH}-\Delta^{5} \mathrm{P}$ production. In support of this notion, male quails which exhibit marked diurnal variations in locomotor activity also show substantial changes in brain level of $7 \alpha-\mathrm{OH}-\Delta^{5} \mathrm{P}$ while female quails which do not show locomotor rhythms have low level of $7 \alpha-\mathrm{OH}-\Delta^{5} \mathrm{P}$ (Tsutsui et al., 2008). Similarly, it has been found that the synthesis of $7 \alpha$ $\mathrm{OH}-\Delta^{5} \mathrm{P}$ in the brain of male newts undergoes marked diurnal changes with higher levels during the dark phase when locomotor activity of males is high. In contrast, $7 \alpha-\mathrm{OH}-\Delta^{5} \mathrm{P}$ production in female newts does not change (Haraguchi et al., 2009, 2010;
Koyama et al., 2009; Tsutsui et al., 2010). In male quail, suppression of endogenous melatonin through pinealectomy $(\mathrm{Px})$ and orbital enucleation (Ex) causes a significant increase of the expression of CYP7B mRNA and biosynthesis of $7 \alpha-\mathrm{OH}-\Delta^{5} \mathrm{P}$ (Tsutsui et al., 2008). ICV injection of melatonin suppresses the effects of Px and Ex on CYP7B gene transcription and $7 \alpha-\mathrm{OH}-\Delta^{5} \mathrm{P}$ production. Finally, the melatonin receptor antagonist luzindole abrogates the inhibitory effect of melatonin on $7 \alpha-\mathrm{OH}-\Delta^{5} \mathrm{P}$ formation (Tsutsui et al., 2008). Collectively, these data support the contention that, in male birds, melatonin inhibits the expression of CYP7B and that the subsequent decrease of $7 \alpha-\mathrm{OH}-\Delta^{5} \mathrm{P}$ in the brain is responsible for the nocturnal reduction of locomotor activity.

\section{EFFECT OF PROLACTIN ON NEUROSTEROID BIOSYNTHESIS}

In male newts, as in many other wild animals, locomotor activity increases during the breeding season (Iwata et al., 2000). This hyperlocomotor response is associated with a concomitant increase in $7 \alpha-\mathrm{OH}-\Delta^{5} \mathrm{P}$ in the newt brain (Haraguchi et al., 2009, 2010). The pituitary hormone prolactin (PRL) exerts pleiotropic functions in the control of reproduction in urodeles (PolzonettiMagni et al., 1995; Kikuyama et al., 2003). In particular, PRL is involved in migration to water at the breeding season (Chadwick, 1941) and stimulates expression of courtship behavior with rapid tail vibration by male newts (Toyoda et al., 1993). Indeed, in male newts, plasma PRL concentration increases during the breeding season (Matsuda et al., 1990; Mosconi et al., 1994) and it has been shown that PRL acts centrally to activate courtship behavior (Toyoda et al., 2005), suggesting that PRL may be involved in the control of $7 \alpha-\mathrm{OH}-\Delta^{5} \mathrm{P}$ synthesis in the brain to increase locomotor activity during the reproductive period. In support of this hypothesis, PRL receptor immunoreactivity is observed in CYP7B-expressing neurons in the anterior preoptic area (Poa) and the magnocellular preoptic nucleus $(\mathrm{Mg})$ of the newt brain (Haraguchi et al., 2010). Hypophysectomy markedly reduces brain concentration and biosynthesis of $7 \alpha-\mathrm{OH}-\Delta^{5} \mathrm{P}$ in breeding male newts and these effects are suppressed by ICV injection of PRL (Haraguchi et al., 2010). Reciprocally, ICV administration of newt PRL antiserum dose-dependently decreases $7 \alpha-\mathrm{OH}-\Delta^{5} \mathrm{P}$ synthesis (Haraguchi et al., 2010). Taken together, these observations indicate that PRL directly acts on $\mathrm{Mg}$ neurons expressing CYP7B to enhance the biosynthesis of $7 \alpha-\mathrm{OH}-\Delta^{5} \mathrm{P}$ which in turn mediates the stimulatory effect of PRL on locomotion.

\section{EFFECT OF GABA ON NEUROSTEROID BIOSYNTHESIS}

Gamma-aminobutyric acid (GABA) is the major neurotransmitter in the CNS (Krnjevic and Schwartz, 1966; Meldrum, 1982; Paredes and Agmo, 1992). In mammals, brain nuclei that express steroidogenic enzymes (Tsutsui et al., 1999; Do Rego et al., 2009) are innervated by GABAergic nerve fibers (Tappaz et al., 1983; Sakaue et al., 1988) and are also enriched with $\mathrm{GABA}_{\mathrm{A}}$ receptors (De Montis et al., 1981; McDonald and Mascagni, 1996; Bäckberg et al., 2004), suggesting that GABA may regulate the activity of steroidogenic nerve cells. As a matter of fact, pharmacological studies have shown that administration of the GABA synthesis inhibitor isoniazid induces an increase of endogenous $\Delta^{5} \mathrm{P}$ and $\mathrm{P}$ in the rat brain (Barbaccia et al., 1996). In contrast, in rat retinal 
ganglion cells, $\mathrm{GABA}$, acting through $\mathrm{GABA}_{\mathrm{A}}$ receptors, stimulates the biosynthesis of $\Delta^{5} \mathrm{P}$ (Guarneri et al., 1995).

The effect and mechanism of action of GABA in the control of neurosteroidogenesis has been mainly investigated in nonmammalian vertebrate models. Indeed, in amphibians as in mammals, a rich GABAergic innervation (Franzoni and Morino, 1989; Hollis and Boyd, 2005) and a dense accumulation of $\mathrm{GABA}_{\mathrm{A}}$ receptor subunits (Aller et al., 1997) have been observed in hypothalamic regions which contain steroidogenic neurons (MensahNyagan et al., 1994, 1999; Tsutsui et al., 1999; Do Rego et al., 2009). In the frog Rana esculenta, double labeling experiments have shown the presence of $\mathrm{GABA}_{\mathrm{A}}$ receptor $\alpha 3$ and $\beta_{2} / \beta_{3}$ subunit-like immunoreactivity in $3 \beta$-HSD-expressing cell bodies (Figure 1A) in the Poa, the posterior tuberculum, the nucleus of the periventricular organ, and the ventral and dorsal hypothalamic nuclei of the hypothalamus (Do Rego et al., 2000) suggesting that, in amphibians as in mammals, GABA may play a role in the control of neurosteroid biosynthesis. In agreement with this hypothesis, GABA has been shown to inhibit in a dose-dependent manner de novo biosynthesis of various neurosteroids including $17 \mathrm{OH}$ $\Delta^{5} \mathrm{P}, \mathrm{P}, 17 \mathrm{OH}-\mathrm{P}$, and DHEA, by frog hypothalamic explants (Do Rego et al., 2000). The inhibitory effect of GABA on neurosteroid production is mimicked by the $\mathrm{GABA}_{\mathrm{A}}$ receptor agonist muscimol and is blocked by the selective $\mathrm{GABA}_{\mathrm{A}}$ receptor antagonists bicuculline and SR95531, but is not affected by the GABA receptor agonist baclofen (Do Rego et al., 2000). The observation that bicuculline and SR95531 induce on their own a significant stimulation of steroid formation suggests that endogenous GABA exerts a tonic inhibitory control on neurosteroid-producing neurons (Do Rego et al., 2000). These data indicate that GABA inhibits the biosynthesis of neurosteroids through activation of $\mathrm{GABA}_{\mathrm{A}}$ receptors (Figure 1D). Since several neuroactive steroids are potent allosteric regulators of $\mathrm{GABA}_{\mathrm{A}}$ receptor function in amphibians (Le Foll et al., 1997a,b; Hollis et al., 2004) as in mammals (Majewska, 1992; Belelli and Lambert, 2005; Belelli et al., 2006), these observations reveal the existence of an ultrashort feedback loop through which certain neurosteroids may regulate their own production via modulation of $\mathrm{GABA}_{\mathrm{A}}$ receptor activity (Figure 1D).

\section{EFFECT OF ENDOZEPINES ON NEUROSTEROID BIOSYNTHESIS}

The term endozepines designates a family of endogenous peptides that act as natural ligands of CBRs and peripheral-type benzodiazepine receptors also called translocator protein (TSPO; Tonon et al., 2006). The occurrence of endozepines has been reported in the CNS of all classes of vertebrates including fish (Malagon et al., 1992b; Matsuda et al., 2007), amphibians (Malagon et al., 1992a; Lihrmann et al., 1994), birds (Todaro et al., 1991; Rose et al., 1992), and mammals (Alho et al., 1989; Tonon et al., 1990; Tong et al., 1991; Malagon et al., 1993). The endozepine family encompasses diazepam-binding inhibitor (DBI), an 86-amino acid polypeptide (Guidotti et al., 1983), and its processing products the triakontatetraneuropeptide (TTN) and the octadecaneuropeptide (ODN; Ferrero et al., 1984; Slobodyansky et al., 1989). TTN is a selective ligand of TSPO (Slobodyansky et al., 1989; Papadopoulos et al., 2006) while ODN acts as an inverse agonist of CBRs
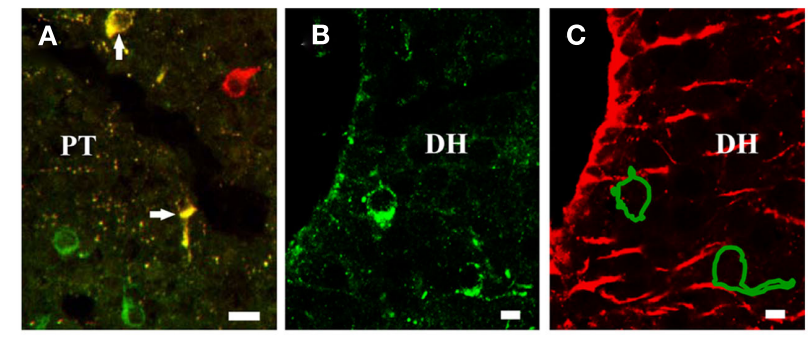

D

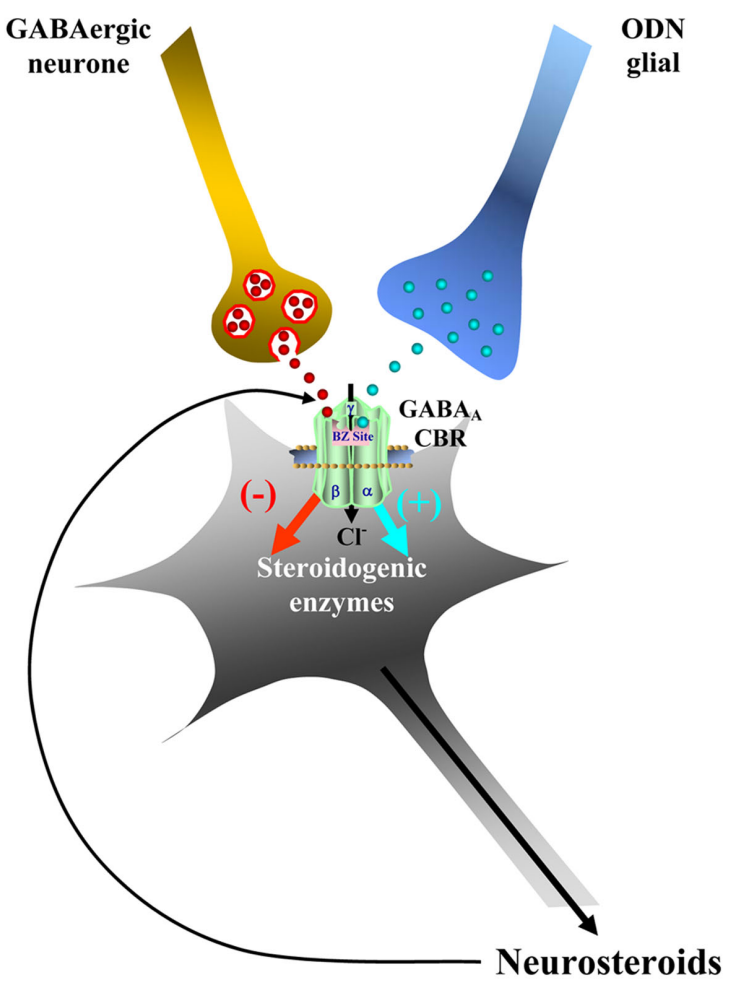

FIGURE 1 | Effect of GABA and the octadecaneuropeptide ODN on neurosteroid biosynthesis. (A) Immunohistochemical localization of $3 \beta$-HSD-like immunoreactivity (red) and $\mathrm{GABA}_{\mathrm{A}}$ receptor $\beta_{2} / \beta_{3}$ subunit-like immunoreactivity (green) in the posterior tuberculum (PT) of the frog brain. $3 \beta$-HSD-positive neurons that possess GABA receptor $\beta_{2} / \beta_{3}$ subunits appear in yellow. (B) Immunohistochemical localization of $3 \beta$-HSD-like immunoreactivity in the dorsal hypothalamic nucleus ( $\mathrm{DH}$; green). (C) Consecutive section to $B$ showing the immunohistochemical localization of ODN-like immunoreactivity in glial cells bordering the third ventricle (red). The contours of two $3 \beta$-HSD-positive neurons labeled in B are shown. For details regarding antibodies and immunohistochemical procedures, see references by Malagon et al. (1992a) and Do Rego et al. (2000, 2001). In brief, polyclonal antibodies raised in rabbit were used to label $3 \beta$-HSD-containing neurons, a mouse monoclonal antibody was used to label GABA receptor $\beta_{2} / \beta_{3}$ subunit-expressing cells, and polyclonal antibodies raised in rabbit were used to label ODN-immunoreactive glial cells. Scale bars: $10 \mu \mathrm{m}$. (D) Schematic drawing depicting the effects of GABA and ODN on steroidogenic neurons. GABA acting through GABA receptors, inhibits the biosynthesis of neurosteroids, while the endozepine ODN, released by glial fibers, acting as an inverse agonist on central-type benzodiazepine receptors (CBR), stimulates the biosynthesis of $170 \mathrm{H}-\Delta^{5} \mathrm{P}$, DHEA, $170 \mathrm{H}-\mathrm{P}$, and P. Neurosteroids, released by these neurons, may in turn modulate allosterically the activity of the $\mathrm{GABA}_{\mathrm{A}}$ receptor and thus control their own biosynthesis. 
(Ferrero et al., 1984). Endozepines have been shown to regulate steroid secretion by adrenocortical cells (Yanagibashi et al., 1989; Papadopoulos, 1993; Lesouhaitier et al., 1996, 1998) and Leydig cells (Papadopoulos et al., 1990, 1991a,b; Garnier et al., 1993, 1994; Duparc et al., 2003). Concurrently, it has been found that TTN stimulates $\Delta^{5} \mathrm{P}$ biosynthesis by isolated mitochondria from C6 glioma cells (Papadopoulos et al., 1992) indicating that endozepines may be involved in the regulation of neurosteroid production.

The distribution of endozepines has been investigated in the brain of mammals and amphibians by in situ hybridization and immunohistochemistry. In the rat brain, DBI mRNA is expressed in various glial cell populations of the ependyma, area postrema, and cerebellum (Alho et al., 1988; Tong et al., 1991; Bürgi et al., 1999). In rat, monkey, and human, endozepine immunoreactivity is found in astrocytes in the arcuate nucleus of the hypothalamus, ependymocytes bordering the third ventricle, tanycytes in the median eminence, pituicytes in the neurohypophysis, and Bergman cells in the cerebellum (Slobodyansky et al., 1992; Malagon et al., 1993; Alho et al., 1995; Yanase et al., 2002). In the frog R. esculenta, DBI mRNA and ODN-like immunoreactivity are present in radial glial cells of the periventricular systems of the diencephalon and rhombencephalon (Malagon et al., 1992a; Lihrmann et al., 1994). Immunolabeling of consecutive sections revealed that, in the Poa, the dorsal and ventral hypothalamic nuclei, the nucleus of the periventricular organ, and the posterior tuberculum of the frog brain, ODN-immunoreactive ependymocytes project toward $3 \beta$-HSD-positive perikarya (Do Rego et al., 2001; Figures 1B,C). These neuroanatomical observations led us to investigate the possible effects of endozepines on neurosteroid biosynthesis in the diencephalon of amphibians.

Incubation of frog hypothalamic slices with graded concentrations of human and rat ODN induces a dose-dependent stimulation of the conversion of $\left[{ }^{3} \mathrm{H}\right] \Delta^{5} \mathrm{P}$ into $\Delta^{4}$-3-ketosteroids and $\Delta^{5}$-3 $\beta$-hydroxysteroids in vitro (Do Rego et al., 2001). The biological activity of ODN is borne by the C-terminal portion of the peptide (Do Rego et al., 2007b) whose sequence has been strongly preserved across vertebrate species (Mocchetti et al., 1986; Lihrmann et al., 1994; Tonon et al., 2006). The stimulatory action of ODN on neurosteroid biosynthesis is mimicked by $\beta$-carbolines that act as inverse agonists of CBR, and is blocked by the CBR antagonist flumazenil (Do Rego et al., 2001). The fact that flumazenil alone inhibits the formation of neurosteroids supports the view that ODN plays a physiological role as an endogenous positive modulator of CBR (Do Rego et al., 2001; Figure 1D).

In intact mammalian endocrine cells, TTN stimulates the secretion of glucocorticoids (Yanagibashi et al., 1989; Papadopoulos et al., 1991a) and testosterone (Garnier et al., 1993; Duparc et al., 2003). TTN also stimulates steroidogenesis by mitochondria isolated from adrenocortical and testicular Leydig cells (Besman et al., 1989; Yanagibashi et al., 1989; Papadopoulos et al., 1991a). In frog adrenal tissue, TTN stimulates corticosterone and aldosterone secretion in vitro (Lesouhaitier et al., 1996, 1998). Since TSPO is expressed not only in peripheral organs but also in the CNS (Braestrup and Squires, 1977; Benavides et al., 1983a,b; Anholt et al., 1984; Richards and Möhler, 1984; Gehlert et al., 1985), these observations suggest that TTN may be involved in the regulation of neurosteroidogenesis. To test this hypothesis, we have investigated the effect of TTN on the biosynthesis of steroids in the brain of amphibians.

Double labeling experiments have shown the presence of TSPO-like immunoreactivity in steroidogenic neurons of the frog Poa and dorsal hypothalamus (Do Rego et al., 1998; Figure 2A). Exposure of frog hypothalamic fragments to synthetic human TTN causes a concentration-dependent stimulation of the conversion of $\left[{ }^{3} \mathrm{H}\right] \Delta^{5} \mathrm{P}$ into $17 \mathrm{OH}-\Delta^{5} \mathrm{P}$ and $17 \mathrm{OH}-\mathrm{P}$ (Do Rego et al., 1998). The TSPO agonist Ro5-4864 mimics the stimulatory effect of TTN while the TSPO antagonist PK11195 inhibits TTN-induced steroid production. In contrast, the action of TTN is not impaired by flumazenil, indicating that TTN acts specifically through TSPO to activate neurosteroid biosynthesis (Do Rego et al., 1998; Figure 2B).

The fact that ODN and TTN, acting via CBR and TSPO, respectively, stimulate the formation of a number of neurosteroids suggests that endozepines should play multiple functions. Indeed, in vivo studies indicate that endozepines, like neurosteroids, exert numerous behavioral effects. In particular, endozepines induce anxiety (Guidotti, 1991; Garcia de Mateos-Verchere et al., 1999), increase aggressivity (Guidotti et al., 1983; Ferrero et al., 1984; Kavaliers and Hirst, 1986; Guidotti, 1991), and possess anticonvulsant properties (Garcia de Mateos-Verchere et al., 1999). In addition, endozepines are potent anorexigenic neuropeptides (Garcia de Mateos-Verchere et al., 2001; Do Rego et al., 2007). Since endozepines and neurosteroids are involved in the control of the same behavioral processes, it is conceivable that neurosteroids can mediate some of the neurobiological effects of endozepines.

\section{EFFECTS OF VASOTOCIN AND MESOTOCIN ON NEUROSTEROID BIOSYNTHESIS}

Anatomical studies support the existence of neurochemical communication between steroidogenic neurons on the one hand, and neurons producing either arginine vasopressin (AVP) and oxytocin (OXT) in mammals or their orthologs arginine vasotocin (AVT) and mesotocin (MT) in submammalian vertebrates on the other hand. For instance, in birds, AVT-immunoreactive fibers innervate aromatase-expressing neurons in the preoptic nucleus and the lateral septum (Viglietti-Panzica et al., 1994; Balthazart, 1997). In the brain of amphibians, AVT- and/or MT-containing fibers project in the vicinity of $3 \beta$-HSD- and $\mathrm{P} 450_{\mathrm{C} 17}$-positive neurons (Do Rego et al., 2006; Figure 3A). In addition, the Poa, the dorsal and ventral hypothalamic nuclei, the suprachiasmatic nucleus, the posterior tuberculum, the nucleus of the periventricular organ, and the ventral part of the magnocellular preoptic nucleus of the frog diencephalon that contain the major populations of steroidogenic neurons are also enriched with AVP and MT receptor mRNAs. These close neuroanatomical relationships led us to investigate the possible effects of AVT and MT on neurosteroid biosynthesis in amphibians.

Static incubation of frog hypothalamic explants with AVT or MT stimulates the biosynthesis of $17 \mathrm{OH}-\Delta^{5} \mathrm{P}, \mathrm{P}, 17 \mathrm{OH}-\mathrm{P}$, and DHEA in a concentration-dependent manner (Do Rego et al., 2006). This stimulatory effect is observed within the first 30-min, indicating that AVT and MT act at the post-translational level, possibly by activating phosphorylation of steroidogenic enzymes. 


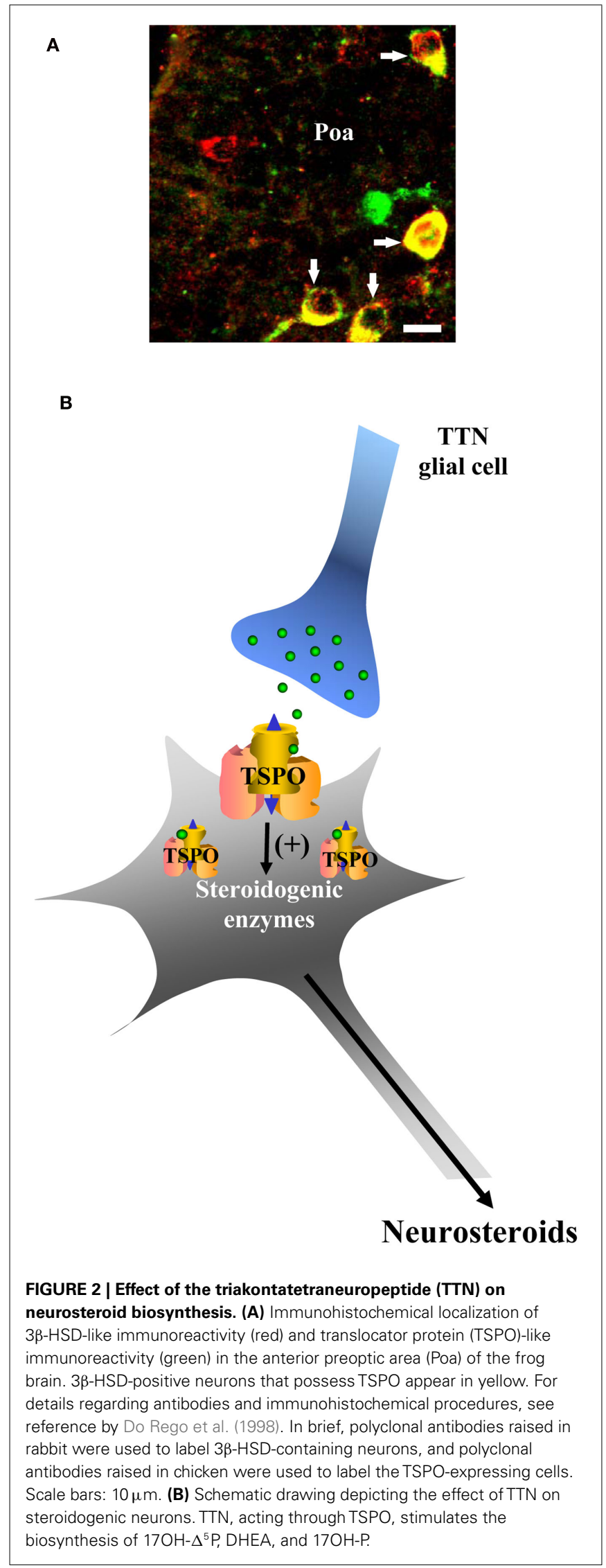

A

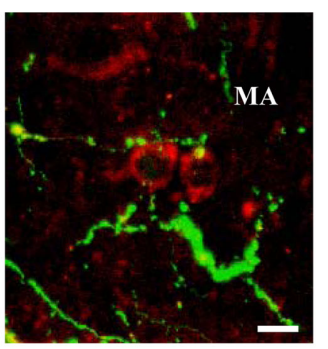

B

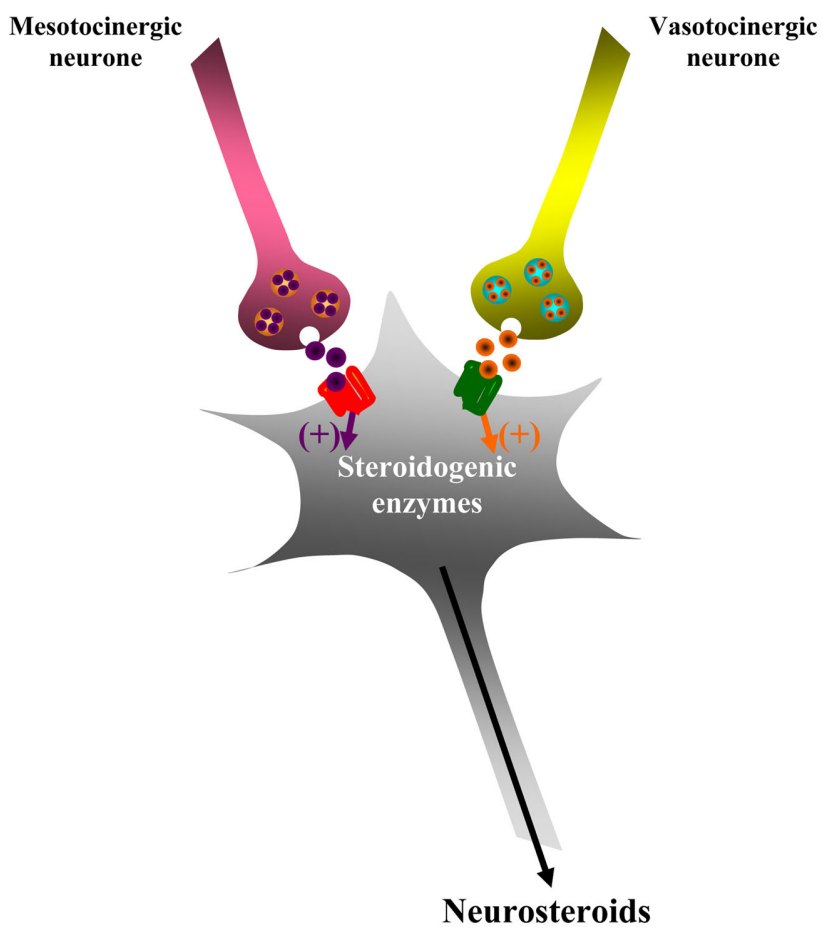

FIGURE 3 | Effect of vasotocin (AVT) and mesotocin (MT) on neurosteroid biosynthesis. (A) Immunohistochemical localization of P450 17 -like immunoreactivity (red) and AVT-like immunoreactivity (green) in the medial amygdala (MA) of the frog brain. AVT-containing nerve endings

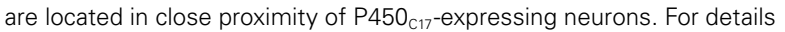
regarding antibodies and immunohistochemical procedures, see reference by Do Rego et al. (2006). In brief, polyclonal antibodies raised in rabbit were

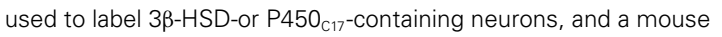
monoclonal antibody was used to label AVT-immunoreactive fibers. Scale bars: $10 \mu \mathrm{m}$. (B) Schematic drawing depicting the effects of AVT and MT on steroidogenic neurons. AVT acting through a V1a-like receptor, and MT acting through an MT receptor, stimulate the biosynthesis of $17 \mathrm{OH}-\Delta^{5} \mathrm{P}$, DHEA, $17 \mathrm{OH}-\mathrm{P}$, and $\mathrm{P}$.

The mammalian peptides AVP and OXT also induce a dose-related stimulation of neurosteroid biosynthesis (Do Rego et al., 2006). Pharmacological studies conducted with specific AVT and MT agonists and antagonists revealed that the effect of AVT and MT are mediated through V1a and MT receptors, respectively (Do Rego et al., 2006; Figure 3B). These observations are in agreement with the intense expression of V1a and MT receptor mRNAs in the hypothalamic nuclei that contain neurosteroidogenic neurons (Do Rego et al., 2006). Interestingly, in frog adrenocortical cells, AVT 
is also a potent stimulator of corticosteroid secretion although, in this latter case, AVT acts via V2 receptors (Larcher et al., 1989, 1992).

In vertebrates, AVP and related peptides exert a vast array of biological effects in the CNS (De Wied et al., 1993; Reghunandanan et al., 1998). For instance, in mammals, AVP enhances learning and memory (Alescio-Lautier and Soumireu-Mourat, 1998; Croiset et al., 2000; Engelmann et al., 2000; Engelmann, 2008) and increases aggressivity and anxiety-like behaviors (Ferris et al., 1997; Everts and Koolhaas, 1999; Heinrichs and Domes, 2008; Amikishieva et al., 2011; Mak et al., 2011; Meyer-Lindenberg et al., 2011). In birds, depending of the species, AVT increases or attenuates aggressive behavior (Goodson et al., 2004, 2009; Dewan et al., 2011). In amphibians, AVT stimulates vocalization and courtship behavior (Woolley et al., 2004; Moore et al., 2005; Thompson et al., 2008; Kikuyama et al., 2009). Certain neurosteroids also affect cognitive and mnemonic functions, aggressiveness and sexual activity (Frye, 2001; Vallée et al., 2001; Darnaudery et al., 2002; MacKenzie et al., 2007; Morrow, 2007). It thus appears that some of the behavioral effects of AVP/AVT may be ascribed to their stimulatory action on neurosteroid biosynthesis.

\section{EFFECT OF NEUROPEPTIDE Y ON NEUROSTEROID BIOSYNTHESIS}

Hydroxysteroid sulfotransferase (HST) catalyzes the transfer of a sulfate moiety from $3^{\prime}$-phosphoadenosine $5^{\prime}$-phosphosulfate (PAPS, a universal donor of sulfate radical) on the 3-hydroxyl group of steroids (Klaassen and Boles, 1997; Strott, 2002). While the presence of HST-containing neurons has been clearly demonstrated in the amphibian hypothalamus (Beaujean et al., 1999; Vaudry et al., 2011), the existence of HST in the brain of mammals is still a matter of debate (Geese and Raftogianis, 2001; Shimada et al., 2001; Shimizu et al., 2003; Kohjitani et al., 2006). Neuropeptide Y (NPY) is one of the most widely distributed biologically active peptides in the CNS of vertebrates (Allen et al., 1983; De Quidt and Emson, 1986; Bons et al., 1990; Danger et al., 1990, 1991; Aste et al., 1991; Hendry, 1993) and NPY, like sulfated neurosteroids, exerts a wide range of neurobiological activities (Dumont and Quirion, 2006).

In frog, the Poa and the magnocellular preoptic nucleus where HST-positive cell bodies are located (Beaujean et al., 1999; Do Rego et al., 2009) are abundantly innervated by NPY-immunoreactive fibers (Danger et al., 1985), suggesting that NPY could play a role in the regulation of HST-expressing neurons. In support of this hypothesis, double labeling experiments revealed that, in the frog diencephalon, numerous NPYergic axon terminals are apposed onto HST-containing perikarya (Beaujean et al., 2002; Figure 4A). In addition, the mRNAs encoding the $Y_{1}$ and $Y_{5}$ NPY receptor subtypes are expressed in the Poa and the magnocellular preoptic nucleus (Beaujean et al., 2002). Incubation of frog hypothalamic tissue with $\left[{ }^{3} \mathrm{H}\right] \Delta^{5} \mathrm{P}$ or $\left[{ }^{3} \mathrm{H}\right]$ DHEA as steroid precursors and $\left[{ }^{35} \mathrm{~S}\right] \mathrm{PAPS}$ as a sulfate donor leads to the biosynthesis of $\left[{ }^{3} \mathrm{H},{ }^{35} \mathrm{~S}\right] \Delta^{5} \mathrm{PS}$ or $\left[{ }^{3} \mathrm{H},{ }^{35} \mathrm{~S}\right]$ DHEAS, respectively, confirming the existence of a biologically active form of HST in the amphibian brain (Beaujean et al., 1999). Synthetic frog NPY (Chartrel et al., 1991) causes a concentration-dependent inhibition of the de novo formation of $\Delta^{5}$ PS and DHEAS (Beaujean et al., 2002). The

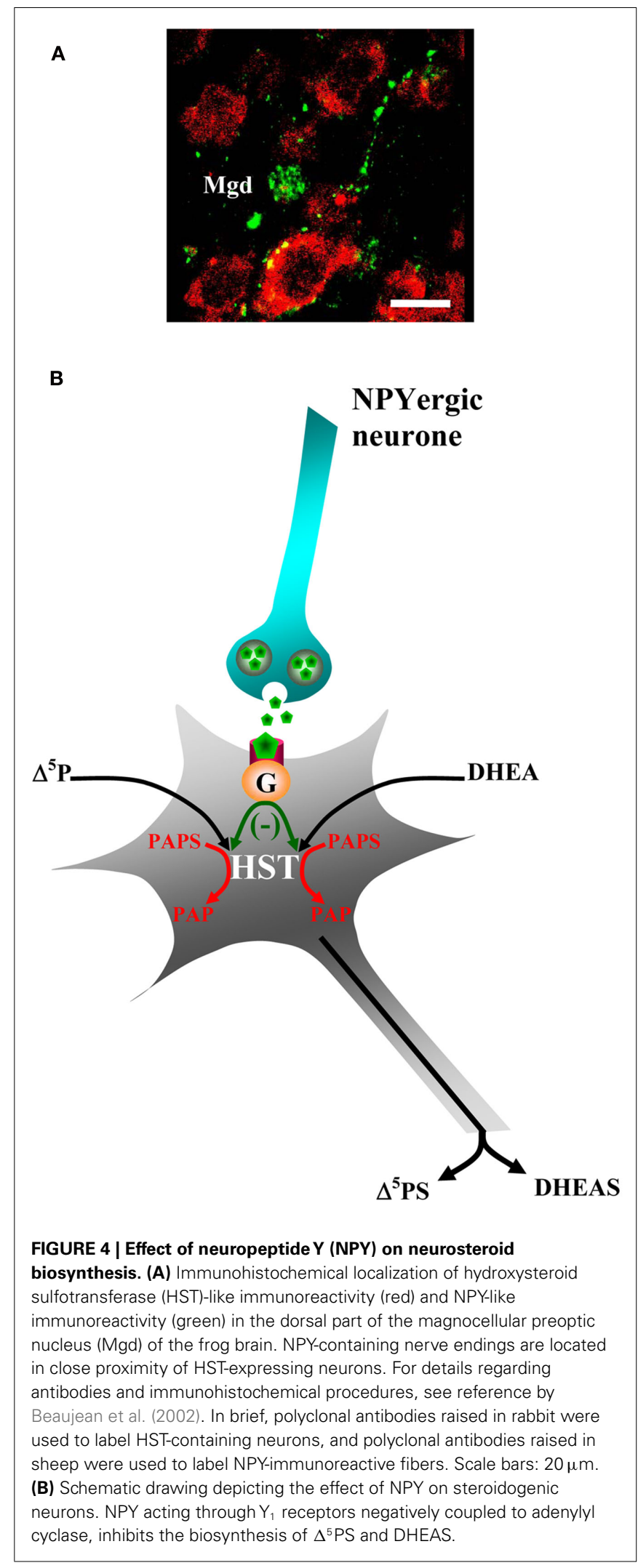

inhibitory effect of NPY is suppressed by the $\mathrm{Y}_{1}$ receptor antagonist BIBP3226 while the $\mathrm{Y}_{2}$ receptor antagonist $\mathrm{NPY}_{(13-36)}$ is 
totally inactive (Beaujean et al., 2002). The fact that the $\mathrm{Y}_{1}$ receptor antagonist per se slightly increases the biosynthesis of $\Delta^{5} \mathrm{PS}$ and DHEAS reveals that endogenous NPY likely acts as a physiological modulator of the formation of sulfated neurosteroids (Beaujean et al., 2002). These data, together with the observation that $Y_{1}$ receptor mRNA is expressed in the Poa and the dorsal magnocellular nucleus, provide strong evidence for a $\mathrm{Y}_{1}$ mediated inhibitory action of NPY on the biosynthesis of sulfated neurosteroids (Figure 4B).

Neuropeptide $\mathrm{Y}$ and sulfated neurosteroids are known to regulate the same behavioral activities including response to novelty (von Horsten et al., 1998; Tasan et al., 2009), feeding and satiety (Kalra and Kalra, 2004a,b; Ramos et al., 2005; Beck, 2006; Ueno et al., 2008), and reproductive behavior (Wehrenberg et al., 1989). NPY and sulfated neurosteroids are also implicated in the physiopathology of cognitive disorders, pain, epilepsy, anxiety, and depression (Engel and Grant, 2001; Rupprecht and Holsboer, 2001; Dumont and Quirion, 2006; Gibbs et al., 2006; Reddy, 2010; Thorsell, 2010; Nguyen et al., 2011). The fact that NPY reduces the biosynthesis of sulfated neurosteroids would thus indicate that some of the neurophysiological activities of NPY could be attributed to inhibition of HST activity.

\section{CONCLUDING REMARKS}

Studies conducted over the last decade have shown that the biosynthesis of neurosteroids is finely regulated by neurotransmitters (melatonin, GABA), pituitary hormones (prolactin), and various neuropeptides (ODN, TTN, AVT, MT, NPY). Several projects are currently in progress and there is little doubt that additional factors involved in the control of neurosteroid formation will be identified in the near future. As illustrated in the present report, most of the studies aimed at identifying the neurochemical regulation of neurosteroid biosynthesis have been conducted in non-mammalian models, mainly birds and amphibians. It will be now essential to examine whether the same mechanisms are operating in the brain of mammals and to look for their potential physiopathological significance. Little is currently known regarding the molecular

\section{REFERENCES}

Alescio-Lautier, B., and SoumireuMourat, B. (1998). Role of vasopressin in learning and memory in the hippocampus. Prog. Brain Res. 119, 501-521.

Alho, H., Bovolin, P., Jenkins, D., Guidotti, A., and Costa, E. (1989). Cellular and subcellular localization of an octadecaneuropeptide derived from diazepam binding inhibitor: immunohistochemical studies in the rat brain. J. Chem. Neuroanat. 2, 301-318.

Alho, H., Fremeau, R. T. Jr., Tiedge, H., Wilcox, J., Bovolin, P., Broslus, J., Roberts, J. L., and Costa, E. (1988). Diazepam binding inhibitor gene expression: location in brain and peripheral tissues of rat. Proc. Natl. Acad. Sci. U.S.A. 85, 7018-7022.

Alho, H., Kolmer, M., Harjuntausta, T., and Helen, P. (1995). Increased

mechanisms implicated in the regulation of neurosteroid biosynthesis. In particular, it has to be determined whether the neuroendocrine factors controlling neurosteroid production act at the transcriptional level to regulate the expression of the genes encoding the steroidogenic enzymes or at the post-translational level, e.g., to modulate the phosphorylation and thus the activity of these enzymes. The fact that neurosteroids are usually implicated in the same biological processes as the neuroendocrine factors which regulate their biosynthesis strongly suggests that some of the neurophysiological and behavioral activities of these latter factors could be mediated by neurosteroids. To test this hypothesis, it will be necessary to investigate whether specific activities of these regulatory factors are impaired in conditional $\mathrm{KO}$ mice lacking selectively expression of steroidogenic enzymes in the brain. The neuroendocrine regulation of neurosteroid biosynthesis by neurotransmitters, neuropeptides, and hormonal factors is currently an emerging theme that will undoubtedly flourish in the years to come.

\section{ACKNOWLEDGMENTS}

This work was supported by grants from the Institut National de la Santé et de la Recherche Médical (INSERM U413/U982), the Ministère des Affaires Etrangères (France-Québec exchange program to Georges Pelletier and Hubert Vaudry), a FranceQuébec exchange program (INSERM-Fonds de la Recherche en Santé du Québec, FRSQ, to Georges Pelletier and Hubert Vaudry), France-Korean exchange programs (INSERM-Korea Science and Engineering Foundation, KOSEF, to Jae Young Seong and Hubert Vaudry; and Science and Technology Amicable Relationships, STAR, to Jean Luc Do Rego, Jae Young Seong, and Hubert Vaudry), a France-Japan exchange program (INSERM-Japan Society for the Promotion of Science, JSPS, to Kazuyoshi Tsutsui, Hubert Vaudry, and Jean Luc Do Rego), the Plate-Forme Régionale de Recherche en Imagerie Cellulaire de Haute-Normandie (PRIMACEN), and the Région Haute-Normandie. Hubert Vaudry is Associated Researcher at the Research Center in Molecular Endocrinology, Oncology and Genetics, Laval University, Québec.

Peripheral-type benzodiazepine receptors in the central nervous system: localization to olfactory nerves. J. Neurosci. 4, 593-603.

Aste, N., Viglietti-Panzica, C., Fasolo, A., Andreone, C., Vaudry, H., Pelletier, G., and Panzica, G. C. (1991). Localization of neuropeptide Yimmunoreactive cells and fibres in the brain of the Japanese quail. Cell Tissue Res. 265, 219-230.

Bäckberg, M., Ultenius, C., Fritschy, J. M., and Meister, B. (2004). Cellular localization of GABA receptor $\alpha$ subunit immunoreactivity in the rat hypothalamus: relationship with neurons containing orexigenic or anorexigenic peptides. J. Neuroendocrinol. 16, 589-604.

Balthazart, J. (1997). Steroid control and sexual differentiation of brain aromatase. J. Steroid Biochem. Mol. Biol. 61, 323-339.
Balthazart, J., Baillien, M., and Ball, G. F. (2001a). Rapid and reversible inhibition of brain aromatase activity. $J$. Neuroendocrinol. 13, 63-73.

Balthazart, J., Baillien, M., and Ball, G. F. (2001b). Phosphorylation processes mediate rapid changes of brain aromatase activity. $J$. Steroid Biochem. Mol. Biol. 79, 261-277.

Balthazart, J., Baillien, M., Charlier, T. D., Cornil, C. A., and Ball, G. F. (2001c). Multiple mechanisms control brain aromatase activity at the genomic and non-genomic level. J. Steroid Biochem. Mol. Biol. 86, 367-379.

Balthazart, J., Baillien, M., Charlier, T. D., and Ball, G. F. (2003). Calcium-dependent phosphorylation processes control brain aromatase in quail. Eur. J. Neurosci. 17, 1591-1606. 
Barbaccia, M. L., Roscetti, G., Trabucchi, M., Purdy, R. H., Mostallino, M. C., Perra, C., Concas, A., and Biggio, G. (1996). Isoniazid-induced inhibition of GABAergic transmission enhances neurosteroid content in the rat brain. Neuropharmacology 35, 1299-1305.

Baulieu, E. E. (1997). Neurosteroids: of the nervous system by the nervous system, for the nervous system. Recent Prog. Horm. Res. 52, 1-32.

Baulieu, E. E. (1998). Neurosteroids: a novel function of the brain. Psychoneuroendocrinology 23, 963-987.

Baulieu, E. E., Robel, P., and Schumacher, M. (1999). "Neurosteroids: a new regulatory function in the nervous system," eds E. E. Baulieu, P. Robel, and M. Schumacher (Totowa, NJ: Humana Press), 1-26.

Beaujean, D., Do Rego, J. L., Galas, L., Mensah-Nyagan, A. G., Fredriksson, R., Larhammar, D., Fournier, A., Luu-The, V., Pelletier, G., and Vaudry, H. (2002). Neuropeptide Y inhibits the biosynthesis of sulfated neurosteroids in the hypothalamus through activation of $\mathrm{Y} 1$ receptors. Endocrinology 143, 1950-1963.

Beaujean, D., Mensah-Nyagan, A. G., Do Rego, J. L., Luu-The, V., Pelletier, G., and Vaudry, H. (1999). Immunocytochemical localization and biological activity of hydroxysteroid sulfotransferase in the frog brain. $J$. Neurochem. 72, 848-857.

Beck, B. (2006). Neuropeptide Y in normal eating and in genetic and dietary-induced obesity. Philos. Trans. R. Soc. Lond. B Biol. Sci. 361, 1159-1185.

Belelli, D., Bolger, M. B., and Gee, K. W. (1989). Anticonvulsant profile of the progesterone metabolite $3 \alpha$ hydroxy $5 \alpha$-pregnan-20-one. Eur. J. Pharmacol. 166, 325-329.

Belelli, D., Herd, M. B., Mitchell, E. A., Peden, D. R., Vardy, A. W., Gentet, L., and Lambert, J. J. (2006). Neuroactive steroids and inhibitory neurotransmission: mechanisms of action and physiological relevance. Neuroscience 138, 821-829.

Belelli, D., and Lambert, J. J. (2005). Neurosteroids: endogenous regulators of the $\mathrm{GABA}_{\mathrm{A}}$ receptor. Nat. Rev. Neurosci. 6, 565-575.

Benavides, J., Quarteronet, D., Imbault, F., Malgouris, C., Uzan, A., Renault, C., Dubroeucq, M. C., Gueremy, C., and Le Fur, G. (1983a). Labelling of "peripheral-type" benzodiazepine binding sites in the rat brain by using $\left[{ }^{3} \mathrm{H}\right] \mathrm{PK}$ 11195, an isoquinoline carboxamide derivative: kinetic studies and autoradiographic localization. J. Neurochem. 41, 1744-1750.
Benavides, J., Malgouris, C., Imbault, F., Begassat, F., Uzan, A., Renault, C., Dubroeucq, M. C., Gueremy, C., and Le Fur, G. (1983b). "Peripheral type" benzodiazepine binding sites in rat adrenals: binding studies with $\left[{ }^{3} \mathrm{H}\right] \mathrm{PK} 11195$ and autoradiographic localization. Arch. Int. Pharmacodyn. Ther. 266, 38-49.

Bergeron, R., de Montigny, C., and Debonnel, G. (1996). Potentiation of neuronal NMDA response induced by dehydroepiandrosterone and its suppression by progesterone: effects mediated via sigma receptors. J. Neurosci. 16, 1193-1202.

Besman, M. J., Yanagibashi, K., Lee, T. D., Kawamura, M., Hall, P. F., and Shively, J. E. (1989). Identification of des-(Gly-Ile)-endozepine as an effector of corticotropin-dependent adrenal steroidogenesis: stimulation of cholesterol delivery is mediated by the peripheral benzodiazepine receptor. Proc. Natl. Acad. Sci. U.S.A. 86, 4897-4901.

Bons, N., Mestre, N., Petter, A., Danger, J. M., Pelletier, G., and Vaudry, H. (1990). Localization and characterization of neuropeptide $\mathrm{Y}$ in the brain of Microcebus murinus (Primate, Lemurian). J. Comp. Neurol. 298, 343-361.

Bowlby, M. R. (1993). Pregnenolone sulfate potentiation of N-methyl-Daspartate receptor channels in hippocampal neurons. Mol. Pharmacol. 43, 813-819.

Braestrup, C., and Squires, R. F. (1977). Specific benzodiazepine receptors in rat brain characterized by high-affinity $\left({ }^{3} \mathrm{H}\right)$ diazepam binding. Proc. Natl. Acad. Sci. U.S.A. 74, 3805-3809.

Bullock, A. E., Clark, A. L., Grady, S. R., Robinson, S. F., Slobe, B. S., Marks, M. J., and Collins, A. C. (1997). Neurosteroids modulate nicotinic receptor function in mouse striatal and thalamic synaptosomes. J. Neurochem. 68, 2412-2423.

Bürgi, B., Lichtensteiger, W., Lauber, M. E., and Schlumpf, M. (1999). Ontogeny of diazepam binding inhibitor/acyl-CoA binding protein mRNA and peripheral benzodiazepine receptor mRNA expression in the rat. J. Neuroendocrinol. 11, 85-100.

Chadwick, C. S. (1941). Identity of prolactin with water drive factor in Triturus viridescens. Proc. Soc. Exp. Biol. Med. 45, 335-337.

Charalampopoulos, I., Tsatsanis, C., Dermitzaki, E., Alexaki, V. I., Castanas, E., Margioris, A. N., and Gravanis, A. (2004). Dehydroepiandrosterone and allopregnanolone protect sympathoadrenal medulla cells against apoptosis via antiapoptotic Bcl-2 proteins. Proc. Natl. Acad. Sci. U.S.A. 101, 8209-8214.

Chartrel, N., Conlon, J. M., Danger, J. M., Fournier, A., Tonon, M. C., and Vaudry, H. (1991). Characterization of melanotropin-release-inhibiting factor (melanostatin) from frog brain: homology with human neuropeptide Y. Proc. Natl. Acad. Sci. U.S.A. 88, 3862-3866.

Compagnone, N. A., and Mellon, S. H. (1998). Dehydroepiandrosterone: a potential signalling molecule for neocortical organization during development. Proc. Natl. Acad. Sci. U.S.A. 95, 4678-4683.

Compagnone, N. A., and Mellon, S. H. (2000). Neurosteroids: biosynthesis and function of these novel neuromodulators. Front. Neuroendocrinol. 21, 1-56.

Cornil, C., Foidart, A., Minet, A., and Balthazart, J. (2000). Immunocytochemical localization of ionotropic glutamate receptors subunits in the adult quail forebrain. J. Comp. Neurol. 428, 577-608.

Cornil, C. A. (2009). Rapid regulation of brain oestrogen synthesis: the behavioural roles of oestrogens and their fates. J. Neuroendocrinol. 21, 217-226.

Corpéchot, C., Robel, P., Axelson, M., Sjövall, J., and Baulieu, E. E. (1981). Characterization and measurement of dehydroepiandrosterone sulfate in rat brain. Proc. Natl. Acad. Sci. U.S.A. 78, 4704-4707.

Corpéchot, C., Synguelakis, M., Talha, S., Axelson, M., Sjövall, J., Vihko, R., Baulieu, E. E., and Robel, P. (1983). Pregnenolone and its sulfate ester in the rat brain. Brain Res. 270, 119-125.

Costa, E. T., Soto, E. E., Cardoso, R. A. Olivera, D. S., and Valenzuela, C. F. (2000). Acute effects of ethanol on kainate receptors in cultured hippocampal neurons. Alcohol. Clin. Exp. Res. 24, 220-225.

Croiset, G., Nijsen, M. J. M. A., and Kamphuis, P. J. G. H. (2000). Role of corticotrophin-releasing factor, vasopressin and autonomic nervous system in learning and memory. Eur. J. Pharmacol. 405, 225-234.

Damianisch, K., Rupprecht, R., and Lancel, M. (2001). The influence of subchronic administration of the neurosteroid allopregnanolone on sleep in the rat. Neuropsychopharmacology 25, 576-584.

Danger, J. M., Breton, B., Vallarino, M., Fournier, A., Pelletier, G., and
Vaudry, H. (1991). Neuropeptide$\mathrm{Y}$ in the trout brain and pituitary: localization, characterization, and action on gonadotropin release. Endocrinology 128, 2360-2368.

Danger, J. M., Guy, J., Benyamina, J., Jégou, S., Leboulenger, F., Coté, J., Tonon, M. C., Pelletier, G., and Vaudry, H. (1985). Localization and identification of neuropeptide $\mathrm{Y}$ (NPY)-like immunoreactivity in the frog brain. Peptides 6, 1225-1236.

Danger, J. M., Tonon, M. C., Jenks, B. G., Saint-Pierre, S., Martel, J. C., Fasolo, A., Breton, B., Quirion, R., Pelletier, G., and Vaudry, H. (1990). Neuropeptide Y: localization in the central nervous system and neuroendocrine functions. Fundam. Clin. Pharmacol. 4, 307-340.

Darnaudery, M., Pallarès, M., Piazza, P. V., Le Moal, M., and Mayo, W. (2002). The neurosteroid pregnenolone sulfate infused into the medial septum nucleus increases hippocampal acetylcholine and spatial memory in rats. Brain Res. 95, 237-242.

De Montis, G. M., Olianas, M. C., Mulas, G., Lloyd, K. G., and Tagliamonte, A. (1981). GABA receptors distribution in rat substantia nigra. Neurosci. Lett. 23, 257-261.

De Quidt, M. E., and Emson, P. C. (1986). Distribution of neuropeptide Y-like immunoreactivity in the rat central nervous system II. Immunohistochemical analysis. Neuroscience 18, 545-618.

De Wied, D., Diamant, M., and Fodor, M. (1993). Central nervous system effects of the neurohypophyseal hormones and related peptides. Front. Neuroendocrinol. 14, 251-302.

Dewan, A. K., Ramey, M. L., and Tricas, T. C. (2011). Arginine vasotocin neuronal phenotypes, telencephalic fiber varicosities, and social behavior in butterflyfishes (Chaetodontidae): potential similarities to birds and mammals. Horm. Behav. 59, 56-66.

Diotel, N., Do Rego, J. L., Anglade, I., Vaillant, C., Pellegrini, E., Gueguen, M. M., Mironov, S., Vaudry, H., and Kah, O. (2011). Activity and expression of steroidogenic enzymes in the brain of adult zebrafish. Eur. J. Neurosci. 34, 45-56.

Diotel, N., Le Page, Y., Mouriec, K., Tong, S. K., Pellegrini, E., Vaillant, C., Anglade, I., Brion, F., Pakdel, F., Chung, B. C., and Kah, O. (2010). Aromatase in the brain of teleost fish: expression, regulation and putative functions. Front. Neuroendocrinol. 31, 172-192.

Djebaili, M., Hoffman, S. W., and Stein, D. G. (2004). Allopregnanolone and 
progesterone decrease cell death and cognitive deficits after a contusion of the rat pre-frontal cortex. Neuroscience 123, 349-359.

Do Rego, J. C., Orta, M. H., Leprince, J., Tonon, M. C., Vaudry, H., and Costentin, J. (2007). Pharmacological characterization of the receptor mediating the anorexigenic action of the octadecaneuropeptide: evidence for an endozepinergic tone regulating food intake. Neuropsychopharmacology 32, 1641-1648.

Do Rego, J. L., Acharjee, S., Seong, J. Y., Galas, L., Alexandre, D., Bizet, P., Burlet, A., Kwon, H. B., LuuThe, V., Pelletier, G., and Vaudry, H. (2006). Vasotocin and mesotocin stimulate the biosynthesis of neurosteroids in the frog brain. J. Neurosci. 26, 6749-6760.

Do Rego, J. L., Mensah-Nyagan, A. G., Beaujean, D., Leprince, J., Tonon, M. C., Luu-The, V., Pelletier, G., and Vaudry, H. (2001). The octadecaneuropeptide ODN stimulates neurosteroid biosynthesis through activation of central-type benzodiazepine receptors. J. Neurochem. 76, 128-138.

Do Rego, J. L., Mensah-Nyagan, A. G., Beaujean, D., Vaudry, D., Sieghart, W., Luu-The, V., Pelletier, G., and Vaudry, H. (2000). GABA, acting through $\mathrm{GABA}_{\mathrm{A}}$ receptors, inhibits biosynthesis of neurosteroids in the frog hypothalamus. Proc. Natl. Acad. Sci. U.S.A. 97, 13925-13930.

Do Rego, J. L., Mensah-Nyagan, A. G., Feuilloley, M., Ferrara, P., Pelletier, G., and Vaudry, H. (1998). The endozepine triakontatetraneuropeptide diazepam-binding inhibitor [17-50] stimulates neurosteroid biosynthesis in the frog hypothalamus. Neuroscience 83, 555-570.

Do Rego, J. L., Seong, J. Y., Burel, D., Leprince, J., Luu-The, V., Tsutsui, K., Tonon, M. C., Pelletier, G., and Vaudry, H. (2009). Neurosteroid biosynthesis: enzymatic pathways and neuroendocrine regulation by neurotransmitters and neuropeptides. Front. Neuroendocrinol. 30, 259-301.

Do Rego, J. L., Tremblay, Y., Luu-The, V., Repetto, E., Castel, H., Vallarino, M., Bélanger, A., Pelletier, G., and Vaudry, H. (2007a). Immunohistochemical localization and biological activity of the steroidogenic enzyme cytochrome P450 17 $\alpha$ hydroxylase/C17, 20-lyase $\left(\mathrm{P}_{450} \mathrm{C}_{\mathrm{C} 7}\right)$ in the frog brain and pituitary. $J$. Neurochem. 100, 251-268.

Do Rego, J. L., Leprince, J., LuuThe, V., Pelletier, G., Tonon, M. C., and Vaudry, H. (2007b). Structure- activity relationships of a series of analogs of the endozepine octadecaneuropeptide $\left(\mathrm{ODN}_{11-18}\right)$ on neurosteroid biosynthesis by hypothalamic explants. J. Med. Chem. 50, 3070-3076.

Dubrovsky, B. O. (2005). Steroids, neuroactive steroids and neurosteroids in psychopathology. Prog. Neuropsychopharmacol. Biol. Psychiatry 29, 169-192.

Dumont, Y., and Quirion, R. (2006). "Neuropeptide Y," in Handbook of Biologically Active Peptides, ed. A. J. Kastin (New York: Academic Press), 683-688.

Duparc, C., Lefebvre, H., Tonon, M. C., Vaudry, H., and Kuhn, J. M. (2003). Characterization of endozepines in the human testicular tissue: effect of triakontatetraneuropeptide on testosterone secretion. J. Clin. Endocrinol. Metab. 88, 5521-5528.

Engel, S. R., and Grant, K. A. (2001). Neurosteroids and behavior. Int. Rev. Neurobiol. 46, 321-348.

Engelmann, M. (2008). Vasopressin in the septum: not important versus causally involved in learning and memory - two faces of the same coin? Prog. Brain Res. 170, 389-395.

Engelmann, M., Wotjak, C. T., Ebner, K., and Landgraf, R. (2000). Behavioral impact of intraseptally released vasopressin and oxytocin in rats. Exp. Physiol. 85, 125S-130S.

Everts, H. G. J., and Koolhaas, J. M. (1999). Differential modulation of lateral septal vasopressin receptor blockade in spatial learning, social recognition, and anxietyrelated behaviors in rats. Behav. Brain Res. 99, 7-16.

Fahey, J. M., Miller, L. G., and Isaacson, R. L. (1995a). Neurosteroid modulation of locomotor activity in mice. Neurosci. Res. Commun. 17, 159-167.

Fahey, J. M., Lindquist, D. G., Pritchard, G. A., and Miller, L. G. (1995b). Pregnenolone sulfate potentiation of NMDA-mediated increases in intracellular calcium in cultured chick cortical neurons. Brain Res. 669, 183-188.

Ferrero, P., Guidotti, A., and ContiTronconi, B. (1984). A brain octadecaneuropeptide generated by tryptic digestion of DBI (diazepam binding inhibitor) functions as a proconflict ligand of benzodiazepine recognition sites. Neuropharmacology 23, 1359-1362.

Ferris, C. F., Melloni, R. H. Jr., Koppel, G., Perry, K. W., Fuller, R. W., and Delville, Y. (1997). Vasopressin/serotonin interactions in the anterior hypothalamus control aggressive behavior in golden hamsters. J. Neurosci. 17, 4331-4340.

Flood, J. F., Morley, J. E., and Roberts, E. (1992). Memory-enhancing effects in male mice of pregnenolone and steroids metabolically derived from it. Proc. Natl. Acad. Sci. U.S.A. 89, 1567-1571.

Flood, J. F., Smith, G. E., and Roberts, E. (1988). Dehydroepiandrosterone and its sulfate enhance memory retention in mice. Brain Res. 447 269-278.

Frank, C., and Sagratella, S. (2000). Neuroprotective effects of allopregnenolone on hippocampal irreversible neurotoxicity in vitro. Prog. Neuropsychopharmacol. Biol. Psychiatry 24, 1117-1126.

Franzoni, M. F., and Morino, P. (1989). The distribution of GABAlike-immunoreactive neurons in the brain of the newt, Tritucus cristatus carnifex, and the green frog Rana esculenta. Cell Tissue Res. 255, 155-166.

Frye, C. A. (2001). The role of neurosteroids and non-genomic effects of progestins and androgens in mediating sexual receptivity of rodents. Brain Res. Rev. 37, 201-222.

Garcia de Mateos-Verchere, J., Leprince, J., Tonon, M. C., Vaudry, H., and Costentin, J. (1999). Reduction of pentylenetetrazol-induced convulsions by the octadecaneuropeptide ODN. Peptides 20, 1431-1436.

Garcia de Mateos-Verchere, J., Leprince, J., Tonon, M. C., Vaudry, H., and Costentin, J. (2001). The octadecaneuropeptide [diazepam-binding inhibitor (33-50)] exerts potent anorexigenic effects in rodents. Eur. J. Pharmacol. 414, 225-231.

Garnier, M., Boujrad, N., Ogwuegbu, S. O., Hudson, J. R. Jr., and Papadopoulos, V. (1994). The polypeptide diazepam-binding inhibitor and a higher affinity mitochondrial peripheral-type benzodiazepine receptor sustain constitutive steroidogenesis in the R2C Leydig tumor cell line. J. Biol. Chem. 269, 22105-22112.

Garnier, M., Boujrad, N., Oke, B. O., Brown, A. S., Riond, J., Ferrara, P., Shoyab, M., SuarezQuian, C. A., and Papadopoulos, V. (1993). Diazepam binding inhibitor is a paracrine/autocrine regulator of Leydig cell proliferation and steroidogenesis: action via peripheral-type benzodiazepine receptor and independent mechanisms. Endocrinology 132, 444-458.
Geese, W. J., and Raftogianis, R. B. (2001). Biochemical characterization and tissue distribution of human SULT2B1. Biochem. Biophys. Res. Commun. 288, 280-289.

Gehlert, D. R., Yamamura, H. I., and Wamsley, J. K. (1985). Autoradiographic localization of "peripheraltype" benzodiazepine binding sites in the rat brain, heart and kidney. Naunyn Schmiedebergs Arch. Pharmacol. 328, 454-460.

Gibbs, J. L., Flores, C. M., and Hargreaves, K. M. (2006). Attenuation of capsaicin-evoked mechanical allodynia by peripheral neuropeptide $\mathrm{Y}$ Y1 receptors. Pain 124, 167-174.

Goodson, J. L., Kabelik, D., and Schrock, S. E. (2009). Dynamic neuromodulation of aggression by vasotocin: influence of social context and social phenotype in territorial songbirds. Biol. Lett. 5, 554-556.

Goodson, J. L., Lindberg, L., and Johnson, P. (2004). Effects of central vasotocin and mesotocin manipulations on social behavior in male and female zebra finches. Horm. Behav. 45, 136-143.

Grazzini, E., Guillon, G., Mouillac, B., and Zingg, H. H. (1998). Inhibition of oxytocin receptor function by direct binding of progesterone. Nature 392, 509-512.

Guarneri, P., Guarneri, R., Cascio, C., Piccoli, F., and Papadopoulos, V. (1995). $\gamma$-aminobutyric acid type $\mathrm{A} /$ benzodiazepine receptors regulate rat retina neurosteroidogenesis. Brain Res. 683, 65-72.

Guidotti, A. (1991). Role of DBI in brain and its posttranslational processing products in normal and abnormal behavior. Neuropharmacology 30, 1425-1433.

Guidotti, A., Forchetti, C. M., Corda, M. G., Kondel, D., Bennett, C. D., and Costa, E. (1983). Isolation, characterization and purification to homogeneity of an endogenous polypeptide with agonistic action on benzodiazepine receptors. Proc. Natl. Acad. Sci. U.S.A. 80, 3531-3535.

Gursoy, E., Cardounel, A., and Kalimi, A. (2001). Pregnenolone protects mouse hippocampal (HT-22) cells against glutamate and amyloid beta protein toxicity. Neurochem. Res. 26, 15-21.

Harada, N. (1988). Novel properties of human placental aromatase as cytochrome P-450: purification and characterization of a unique form of aromatase. J. Biochem. 103, 106-113.

Haraguchi, S., Koyama, T., Do Rego, J. L., and Tsutsui, K. (2009). Seasonal changes in the synthesis of $7 \alpha$-hydroxypregnenolone 
stimulating locomotor activity in newts. Ann. N. Y. Acad. Sci. 1163 , 410-413.

Haraguchi, S., Koyama, T., Hasunuma, I., Vaudry, H., and Tsutsui, K. (2010). Prolactin increases the synthesis of $7 \alpha$-hydroxypregnenolone, a key factor for induction of locomotor activity, in breeding male newts. Endocrinology 151, 2211-2222.

Hau, M., and Gwinner, E. (1994). Melatonin facilitates synchronization of sparrow circadian rhythms to light. J. Comp. Physiol. A 175, 343-347.

He, J., Hoffman, S. W., and Stein, D. G. (2004). Allopregnanolone, a progesterone metabolite, enhances behavioral recovery and decreases neuronal loss after traumatic brain injury. Restor. Neurol. Neurosci. 22, 19-31.

Heinrichs, M., and Domes, G. (2008). Neuropeptides and social behavious: effect of oxytocin and vasopressin in humans. Prog. Brain Res. 170, 337-350.

Hendry, S. H. (1993). "Organization of neuropeptide $\mathrm{Y}$ neurons in the mammalian central nervous system," in The Biology of Neuropeptide Y and Related Peptides, eds W. F. Colmers and C. Wahlested (Totowa, NJ: Humana Press), 65-156.

Hodge, C. W., Raber, J., McMahon, T., Walter, H., Sanchez-Perez, A. M., Olive, M. F., Mehmert, K., Morrow, A. L., and Messing, R. O. (2002). Decreased anxiety-like behavior, reduced stress hormones, and neurosteroid supersensitivity in mice lacking protein kinase Cepsilon. J. Clin. Invest. 110, 1003-1010.

Hollis, D. M., and Boyd, S. K. (2005). Distribution of GABA-like immunoreactive cell bodies in the brains of two amphibians, Rana catesbeiana and Xenopus laevis. Brain Behav. Evol. 65, 127-142.

Hollis, D. M., Goetz, F. W., Roberts, S. B., and Boyd, S. K. (2004). Acute neurosteroid modulation and subunit isolation of the gammaaminobutyric $\operatorname{acid}_{\mathrm{A}}$ receptor in the bullfrog, Rana catesbeina. J. Mol. Endocrinol. 32, 921-934.

Horishita, T., Minami, K., Uezono, Y., Shiraishi, M., Ogata, J., Okamoto, T., Terada, T., and Sata, T. (2005). The effects of the neurosteroids: pregnenolone, progesterone and dehydroepiandrosterone on muscarinic receptor-induced responses in Xenopus oocytes expressing M1 and M3 receptors. Naunyn Schmiedebergs Arch. Pharmacol. 371, 221-228.

$\mathrm{Hu}$, Y., Cardounel, A., Gursoy, E., Anderson, P., and Kalimi, M. (2000). Anti-stress effects of dehydroepiandrosterone: protection of rats against repeated immobilization stress-induced weight loss, glucocorticoid receptor production, and lipid peroxidation. Biochem. Pharmacol. 59, 753-762.

Inai, Y., Nagai, K., Ukena, K., Oishi, T., and Tsutsui, K. (2003). Seasonal changes in neurosteroid concentrations in the amphibian brain and environmental factors regulating their changes. Brain Res. 959, 214-225.

Irwin, R. P., Maragakis, N. J., Rogawski, M. A., Purdy, R. H., Farb, D. H., and Paul, S. M. (1992). Pregnenolone sulfate augments NMDA receptor mediated increases in intracellular $\mathrm{Ca}^{2+}$ in cultured rat hippocampal neurons. Neurosci. Lett. 141, 30-34.

Iwata, M., Muneoka, K. T., Shirayama, Y., Yamamoto, A., and Kawahara, R. (2005). A study of a dendritic marker, microtubuleassociated protein 2 (MAP-2), in rats neonatally treated neurosteroids, pregnenolone and dehydroepiandrosterone (DHEA). Neurosci. Lett. 386, 145-149.

Iwata, T., Toyoda, F., Yamamoto, K., and Kikuyama, S. (2000). Hormonal control of urodele reproductive behavior. Comp. Biochem. Physiol. B. Biochem. Mol. Biol. 126, 221-229.

Jiang, P., Yang, C. X., Wang, Y. T., and Xu, T. L. (2006). Mechanisms of modulation of pregnanolone on glycinergic response in cultured spinal dorsal horn neurons of rat. Neuroscience 141, 2041-2050.

Jo, D. H., Sánchez de la Peña, S., Halberg, F., Ungar, F., Baulieu, E. E., and Robel, P. (1990). Circadianinfradian rhythmic variation of brain neurosteroids in the female rat. Prog. Clin. Biol. Res. 341B, 125-134.

Jones, K. (1994). Androgenic enhancement of motor neuron regeneration. Ann. N. Y. Acad. Sci. 743, 141-164.

Kalra, S. P., and Kalra, P. S. (2004a). NPY and cohorts in regulating appetite, obesity and metabolic syndrome: beneficial effects of gene therapy. Neuropeptides 38, 201-211.

Kalra, S. P., and Kalra, P. S. (2004b). NPY: an endearing journey in search of a neurochemical on/off switch for appetite, sex and reproduction. Peptides 25, 465-471.

Kaur, G., and Kulkarni, S. K. (2001). Subchronic studies on modulation of feeding behavior and body weight by neurosteroids in female mice. Methods Find. Exp. Clin. Pharmacol. 23, 115-119.

Kavaliers, M., and Hirst, M. (1986). An octadecaneuropeptide (ODN) derived from diazepam binding inhibitor increases aggressive interactions in mice. Brain Res. 383, 343-349.

Kavaliers, M., and Kinsella, D. M. (1995). Male preference for the odors of estrous female mice is reduced by the neurosteroid pregnenolone sulfate. Brain Res. 682, 222-226.

Kikuyama, S., Hasunuma, I., Toyoda, F., Haraguchi, S., and Tsutsui, K. (2009). Hormone-mediated reproductive behavior in the red-bellied newt. Ann. N. Y. Acad. Sci. 1163, 79-86.

Kikuyama, S., Tanaka, S., and Moore, F. L. (2003). "Reproductive biology and phylogeny of urodela," in Endocrinology of Reproduction, ed. D. M. Sever (Enfield, NH: Science Publishers), 275-321.

Kimonides, V. G., Khatibi, N. H., Svendsen, C. N., Sofroniew, M. V., and Herbert, J. (1998). Dehydroepiandrosterone (DHEA) and DHEA-sulfate (DHEAS) protect hippocampal neurons against excitatory amino acidinduced neurotoxicity. Proc. Natl. Acad. Sci. U.S.A. 95, 1852-1857.

Kimonides, V. G., Spillantini, M. G. Sofroniew, M. V., fawcett, J. W. and Herbert, J. (1999). Dehydroepiandrosterone antagonizes the neurotoxic effects of corticosterone and translocation of stress-activated protein kinase 3 in hippocampal primary cultures. Neuroscience 89, 429-436.

Klaassen, C. D., and Boles, J. W. (1997). Sulfation and sulfotransferases 5: the importance of $3^{\prime}$-phosphoadenosine $5^{\prime}$-phosphosulfate (PAPS) in the regulation of sulfation. FASEB J. 11, 404-418.

Koenig, H. L., Schumacher, M., Ferzaz, B., Do, T. A. N., Ressouches, A., Guennoun, R., Jung-Testas, I., Robel, P., Akwa, Y., and Baulieu, E. E. (1995). Progesterone synthesis and myelin formation by Schwann cells. Science 268, 1500-1503.

Kohjitani, A., Fuda, H., Hanyu, O., and Strott, C. A. (2006). Cloning, characterization and tissue expression of rat SULT2B1a and SULT2B1b steroid/sterol sulfotransferase isoforms: divergence of the rat SULT2B1 gene structure from orthologous human and mouse genes. Gene 367, 66-73.

Kostowski, W., and Bienkowski, P. (1999). Discriminative stimulus effects of ethanol: neuropharmacological characterization. Alcohol 17, 63-80.

Koyama, T., Haraguchi, S., Vaudry, H. and Tsutsui, K. (2009). Diurnal changes in the synthesis of $7 \alpha$ hydroxypregnenolone stimulating locomotor activity in newts. Ann. N. Y. Acad. Sci. 1163, 444-447.

Krnjevic, K., and Schwartz, S. (1966). Is gamma-aminobutyric acid an inhibitory transmitter? Nature 211, 1372-1374.

Ladurelle, N., Eychenne, B., Denton, D., Blair-West, J., Schumacher, M., and Baulieu, E. E. (2000). Prolonged intracerebroventricular infusion of neurosteroids affects cognitive performances in the mouse. Brain Res. 858, 371-379.

Lancel, M., Faulhaber, J., Schiffelholz, T., Romeo, E., di Michele, F., Holsboer, F., and Rupprecht, R. (1997). Allopregnanolone affects sleep in a benzodiazepine-like fashion. J. Pharmacol. Exp. Ther. 282, 1213-1218.

Landgren, S., Backstrom, T., and Dubrovsky, B. (1987). The effect of progesterone and its metabolites on the interictal epileptiform discharge in the cat's cerebral cortex. Acta Physiol. Scand. 131, 33-42.

Lanthier, A., and Patwardhan, V. V. (1986). Sex steroids and 5-en-3 $\beta$ hydroxysteroids in specific regions of the human brain and cranial nerves. J. Steroid Biochem. 25, 445-449.

Lapchak, P. A., and Araujo, D. M. (2001). Preclinical development of neurosteroids as neuroprotective agents for the treatment of neurodegenerative diseases. Int. Rev. Neurobiol. 46, 379-397.

Lapchak, P. A., Chapman, D. F., Nunez, S. Y., and Zivin, J. A. (2000). Dehydroepiandrosterone sulfate is neuroprotective in a reversible spinal cord ischemia model. Stroke 31, 1953-1957.

Larcher, A., Delarue, C., HomoDelarche, F., Kikuyama, S., Kupryszewski, G., and Vaudry, H. (1992). Pharmacological characterization of vasotocin stimulation of phosphoinositide turnover in frog adrenal gland. Endocrinology 130, 475-483.

Larcher, A., Delarue, C., Idres, S., Lefebvre, H., Feuilloley, M., Vandesande, F., Pelletier, G., and Vaudry, H. (1989). Identification of VTlike immunoreactivity in chromaffin cells of the frog adrenal gland: effect of VT on corticosteroid secretion. Endocrinology 125, 2691-2700.

Laurine, E., Lafitte, D., Grégoire, C., Sérée, E., Loret, E., Douillard, S., Michel, B., Briand, C., and Verdier, J. M. (2003). Specific binding of dehydroepiandrosterone to the $\mathrm{N}$ terminus of 
the microtubule-associated protein MAP2. J. Biol. Chem. 278, 29979-29986.

Le Foll, F., Louiset, E., Castel, H., Vaudry, H., and Cazin, L. (1997a). Electrophysiological effects of various neuroactive steroids on the GABAA receptor in pituitary melanotrope cells. Eur. J. Pharmacol. 331, 303-311.

Le Foll, F., Castel, H., Louiset, E., Vaudry, H., and Cazin, L. (1997b). Multiple modulatory effects of the neuroactive steroid pregnanolone on GABAA receptor in frog pituitary melanotrophs. J. Physiol. 504, 387-400.

Leskiewicz, M., Budziszewska, B., BastaKaim, A., Zajac, A., Kacinski, M., and Lason, W. (2006). Effects of neurosteroids on neuronal survival: molecular basis and clinical perspectives. Acta Neurobiol. Exp. (Wars.) 66, 359-367.

Lesouhaitier, O., Feuilloley, M., Lihrmann, I., Ugo, I., Fasolo, A., Tonon, M. C., and Vaudry, H. (1996). Localization of diazepambinding inhibitor-related peptides and peripheral type benzodiazepine receptors in the frog adrenal gland. Cell Tissue Res. 283, 403-412.

Lesouhaitier, O., Feuilloley, M., and Vaudry, H. (1998). Effect of the triakontatetraneuropeptide (TTN) on corticosteroid secretion by the frog adrenal gland. J. Mol. Endocrinol. 20, 45-53.

Lihrmann, I., Plaquevent, J. C., Tostivint, H., Raijmakers, R., Tonon, M. C., Conlon, J. M., and Vaudry, H. (1994). Frog diazepam-binding inhibitor: peptide sequence, cDNA cloning, and expression in the brain. Proc. Natl. Acad. Sci. U.S.A. 91, 6899-6903.

Lockhart, E. M., Warner, D. S., Pearlstein, R. D., Penning, D. H., Mehrabani, S., and Boustany, R. M. (2002). Allopregnanolone attenuates $\mathrm{N}$-methyl-D-aspartate-induced excitotoxicity and apoptosis in human NT2 cell line in culture. Neurosci. Lett. 328, 33-36.

MacKenzie, E. M., Odontiadis, J., Le Melledo, J. M., Prior, T. I., and Baker, G. B. (2007). The relevance of neuroactive steroids in schizophrenia, depression, and anxiety disorders. Cell. Mol. Neurobiol. 27, 541-574.

Magnaghi, V., Cavarretta, I., Galbiati, M., Martini, L., and Melcangi, R. C. (2001). Neuroactive steroids and peripheral myelin proteins. Brain Res. Rev. 37, 360-371.

Majewska, M. D. (1992). Neurosteroids: endogenous bimodal modulators of the GABAA receptor. Mechanism of action and physiological significance. Prog. Neurobiol. 38, 379-395.

Majewska, M. D., Harrison, N. L., Schwartz, R. D., Barker, J. L., and Paul, S. M. (1986). Steroid hormone metabolites are barbituratelike modulators of the GABA receptor. Science 232, 1004-1007.

Majewska, M. D., and Schwartz, R. D. (1987). Pregnenolone-sulfate: an endogenous antagonist of the gamma-aminobutyric acid receptor complex in brain? Brain Res. 404, 355-360.

Mak, P., Broussard, C., Vacy, K., and Broadbear, J. H. (2011). Modulation of anxiety behavior in the elevated plus maze using peptidic oxytocin and vasopressin receptor ligands in the rat. J. Psychopharmacol. (in press).

Malagon, M., Vaudry, H., Vallarino, M., Gracia-Navarro, F., and Tonon, M. C. (1992a). Distribution and characterization of endozepine-like immunoreactivity in the central nervous system of the frog Rana ridibunda. Peptides 13, 99-107.

Malagon, M., Vallarino, M., Tonon, M. C., and Vaudry, H. (1992b). Localization and characterization of diazepam-binding inhibitor (DBI)like peptides in the brain and pituitary of the trout (Salmo gairdneri). Brain Res. 576, 208-214.

Malagon, M., Vaudry, H., Van Strien, F., Pelletier, G., Gracia-Navarro, F., and Tonon, M. C. (1993). Ontogeny of diazepam-binding inhibitor-related peptides (endozepines) in the rat brain. Neuroscience 57, 777-786.

Malik, A. S., Narayan, R. K., and Wendling, W. W. (2003). A novel dehydroepiandrosterone analog improves functional recovery in a rat traumatic brain injury model. $J$. Neurotrauma 20, 463-476.

Mameli, M., Carta, M., Partridge, L. D., and Valenzuela, C. F. (2005). Neurosteroid-induced plasticity of immature synapses via retrograde modulation of presynaptic NMDA receptors. J. Neurosci. 25, 2285-2294.

Manji, H. K., Quiroz, J. A., Sporn, J., Payne, J. L., Denicoff, K., and Gray, M. (2003). Enhancing neuronal plasticity and cellular resilience to develop novel, improved therapeutics for difficult-to-treat depression. Biol. Psychiatry 53, 707-742.

Marumoto, N., Murakami, N., Katayama, T., Kuroda, H., and Murakami, T. (1996). Effects of daily injections of melatonin on locomotor activity rhythms in rats maintained under constant bright or dim light. Physiol. Behav. 60, 767-773.
Matsuda, K., Tanaka, S., Yamamoto, K. and Kikuyama, S. (1990). Annual changes of plasma prolactin levels in the newt, Cynops pyrrhogaster. Zool. Sci. 7, 1143

Matsuda, K., Wada, K., Miura, T., Maruyama, K., Shimakura, S. I., Uchiyama, M., Leprince, J., Tonon, M. C., and Vaudry, H. (2007). Effect of the diazepam-binding inhibitor-derived peptide, octadecaneuropeptide, on food intake in goldfish. Neuroscience 150, 425-432.

Matsunaga, M., Ukena, K., Baulieu, E. E., and Tsutsui, K. (2004). $7 \alpha$-Hydroxypregnenolone acts as a neuronal activator to stimulate locomotor activity of breeding newts by means of the dopaminergic system. Proc. Natl. Acad. Sci. U.S.A. 101, 17282-17287.

Maurice, T., Grégoire, C., and Espallergues, J. (2006). Neuro(active)steroids actions at the neuromodulatory sigmal $(\sigma 1)$ receptor: biochemical and physiological evidences, consequences in neuroprotection. Pharmacol. Biochem. Behav. 84, 581-597.

Mayo, W., Dellu, F., Robel, P., Cherkaoui, J., Le Moal, M., Baulieu, E. E., and Simon, H. (1993). Infusion of neurosteroids into the nucleus basalis magnocellularis affects cognitive processes in the rat. Brain Res. 607, 324-328.

McDonald, A. J., and Mascagni, F. (1996). Immunohistochemical localization of the $\beta 2$ and $\beta 3$ subunits of the $\mathrm{GABA}_{\mathrm{A}}$ receptor in the basolateral amygdala of the rat and monkey. Neuroscience 75, 407-419.

McEwen, B. S. (1994). Steroid hormone actions on the brain: when is the genome involved? Horm. Behav. 28 , 396-405.

Melcangi, R. C., Azcoitia, I., Ballabio, M., Cavarretta, I., Gonzalez, L. C., Leonelli, E., Magnaghi, V., Veiga, S., and Garcia-Segura, L. M. (2003). Neuroactive steroids influence peripheral myelination: a promising opportunity for preventing or treating age-dependent dysfunctions of peripheral nerves. Prog. Neurobiol. 71, 57-66.

Meldrum, B. (1982). Pharmacology of GABA. Clin. Neuropharmacol. 5, 293-316.

Mellon, S., and Vaudry, H. (2001). Biosynthesis of neurosteroids and regulation of their synthesis. Int. Rev. Neurobiol. 46, 33-78.

Mellon, S. H., and Griffin, L. D. (2002). Neurosteroids: biochemistry and clinical significance. Trends Endocrinol. Metab. 13, 35-43.
Mensah-Nyagan, A. G., Do Rego, J. L., Beaujean, D., Luu-The, V., Pelletier, G., and Vaudry, H. (1999). Neurosteroids: expression of steroidogenic enzymes and regulation of steroid biosynthesis in the central nervous system. Pharmacol. Rev. 51, 63-81.

Mensah-Nyagan, A. G., Feuilloley, M., Do Rego, J. L., Marcual, A., Lange, C., Tonon, M. C., Pelletier, G., and Vaudry, H. (1996). Localization of $17 \beta$-hydroxysteroid dehydrogenase and characterization of testosterone in the brain of the male frog. Proc. Natl. Acad. Sci. U.S.A. 93, 1423-1428.

Mensah-Nyagan, A. G., Feuilloley, M., Dupont, E., Do Rego, J. L., Leboulenger, F., Pelletier, G., and Vaudry, H. (1994). Immunocytochemical localization and biological activity of $3 \beta$-hydroxysteroid dehydrogenase in the central nervous system of the frog. J. Neurosci. 14, 7306-7318.

Meyer-Lindenberg, A., Domes, G., Kirsch, P., and Heinrichs, M. (2011). Oxytocin and vasopressin in the human brain: social neuropeptides for translational medicine. Nat. Rev. Neurosci. 12, 524-538.

Migues, P. V., Johnston, A. N., and Rose, S. P. (2002). Dehydroepiandrosterone and its sulphate enhance memory retention in day-old chicks. Neuroscience 109, 243-251.

Mitchell, E. A., Gentet, L. J., Dempster, J., and Belelli, D. (2007). GABAA and glycine receptor-mediated transmission in rat lamina II neurones: relevance to the analgesic actions of neuroactive steroids. J. Physiol. 583, 1021-1040.

Mo, Q., Lu, S. F., Hu, S., and Simon, N. G. (2004). DHEA and DHEA sulfate differentially regulate neural androgen receptor and its transcriptional activity. Brain Res. Mol. Brain Res. 126, 165-172.

Mocchetti, I., Einstein, R., and Brosius, J. (1986). Putative diazepam binding inhibitor peptide: $\mathrm{cDNA}$ clones from rat. Proc. Natl. Acad. Sci. U.S.A. 83, 7221-7225

Monnet, F. P., Mahe, V., Robel, P., and Baulieu, E. E. (1995). Neurosteroids, via $\sigma$ receptors, modulate the $\left[{ }^{3} \mathrm{H}\right]$ norepinephrine release evoked by $\mathrm{N}$-methyl-D-aspartate in the rat hippocampus. Proc. Natl. Acad. Sci. U.S.A. 92, 3774-3778.

Monnet, F. P., and Maurice, T. (2006). The sigmal protein as a target for the non-genomic effects of neuro(active)steroids: molecular, physiological, and behavioral aspects. J. Pharmacol. Sci. 100, 93-118. 
Moore, F. L., Boyd, S. K., and Kelley, D. B. (2005). Historical perspective: hormonal regulation of behaviors in amphibians. Horm. Behav. 48, 373-383.

Morrow, A. L. (2007). Recent developments in the significance and therapeutic relevance of neuroactive steroids - introduction to the special issue. Pharmacol. Ther. 116, 1-6.

Mosconi, G., Yamamoto, K., Kikuyama, S., Carnevali, O., Mancuso, A., and Vellano, C. (1994). Seasonal changes of plasma prolactin concentration in the reproduction of the crested newt (Triturus carnifex Laur). Gen. Comp. Endocrinol. 95, 342-349.

Murakami, K., Fellous, A., Baulieu, E. E., and Robel, P. (2000). Pregnenolone binds to microtubuleassociated protein 2 and stimulates microtubule assembly. Proc. Natl. Acad. Sci. U.S.A. 97, 3579-3584.

Murakami, N., Kawano, T., Nakahara, K., Nasu, T., and Shiota, K. (2001). Effect of melatonin on circadian rhythm, locomotor activity and body temperature in the intact house sparrow, Japanese quail and owl. Brain Res. 889, 220-224.

Nasman, B., Olsson, T., Backstrom, T., Eriksson, S., Grankvist, K., Vitanen, M., and Bucht, G. (1991). Serum dehydroepiandrosterone sulfate in Alzeimer's disease and in multiinfarct dementia. Biol. Psychiatry 30, 684-690.

Nguyen, A. D., Herzog, H., and Sainsbury, A. (2011). Neuropeptide Y and peptide YY. Important regulators of energy metabolism. Curr. Opin. Endocrinol. Diabetes Obes. 18, 56-60.

Papadopoulos, V. (1993). Peripheraltype benzodiazepine/diazepam binding inhibitor receptor: biological role in steroidogenic cell function. Endocr. Rev. 14, 222-240.

Papadopoulos, V., Baraldi, M., Guilarte, T. R., Knudsen, T. B., Lacapère, J. J., Lindemann, P., Norenberg, M. D., Nutt, D., Weizman, A., Zhang, M. R., and Gavish, M. (2006). Translocator protein $(18 \mathrm{kDa})$ : new nomenclature for the peripheraltype benzodiazepine receptor based on its structure and molecular function. Trends Pharmacol. Sci. 27, 402-409.

Papadopoulos, V., Berkovich, A., and Krueger, K. E. (1991a). The role of diazepam binding inhibitor and its processing products at mitochondrial benzodiazepine receptors: regulation of steroid biosynthesis. $\mathrm{Neu}$ ropharmacology 30, 1417-1423.

Papadopoulos, V., Berkovich, A., Krueger, K. E., Costa, E., and Guidotti, A. (1991b). Diazepam binding inhibitor and its processing products stimulate mitochondrial steroid biosynthesis via an interaction with mitochondrial benzodiazepine receptors. Endocrinology 129, 1481-1488.

Papadopoulos, V., Guarneri, P., Krueger, K. E., Guidotti, A., and Costa, E. (1992). Pregnenolone biosynthesis in C6-2B glioma cell mitochondria: regulation by a mitochondrial diazepam binding inhibitor receptor. Proc. Natl. Acad. Sci. U.S.A. 89, 5113-5117.

Papadopoulos, V., Mukhin, A. G., Costa, E., and Krueger, K. E. (1990). The peripheral-type benzodiazepine receptor is functionally linked to Leydig cell steroidogenesis. J. Biol. Chem. 265, 3772-3779.

Paredes, R. G., and Agmo, A. (1992). GABA and behavior: the role of receptor subtypes. Neurosci. Biobehav. Rev. 16, 145-170.

Park-Chung, M., Malayev, A., Purdy, R. H., Gibbs, T. T., and Farb, D. H. (1999). Sulfated and unsulfated steroids modulate gammaaminobutyric acid A receptor function through distinct sites. Brain Res. 830, 72-87.

Patchev, V. K., Hassan, A. H. S., Holsboer, F., and Almeida, O. F. X. (1996). The neurosteroid tetrahydroprogesterone attenuates the endocrine response to stress and exerts glucocorticoid-like effects on vasopressin gene transcription in the rat hypothalamus. Neuropsychopharmacology 15, 533-540.

Paul, S. M., and Purdy, S. H. (1992). Neuroactive steroids. FASEB J. 6, 2311-2322.

Pham, J., Porter, J., Svec, D., Eiswirth, C., and Svec, F. (2000). The effect of dehydroepiandrosterone on Zucker rats selected for fat food preference. Physiol. Behav. 70, 431-441.

Pinna, G., Agis-Balboa, R. C., Pibiri, F., Nelson, M., Guidotti, A., and Costa, E. (2008). Neurosteroid biosynthesis regulates sexually dimorphic fear and aggressive behavior in mice. Neurochem. Res. 33, 1990-2007.

Plassart-Schiess, E., and Baulieu, E. E. (2001). Neurosteroids: recent findings. Brain Res. Rev. 37, 133-140.

Polzonetti-Magni, A., Carnevali, O., Yamamoto, K., and Kikuyama, S. (1995). Growth hormone and prolactin in amphibian reproduction. Zool. Sci. 12, 683-694.

Ramos, E. J., Meguid, M. M., Campos, A. C., and Coelho, J. C. (2005). Neuropeptide Y, $\alpha$ melanocyte-stimulating hormone, and monoamines in food intake regulation. Nutrition 21, 269-279.
Reddy, D. S. (2003). Pharmacology of endogenous neuroactive steroids. Crit. Rev. Neurobiol. 15, 197-234.

Reddy, D. S. (2010). Neurosteroids: endogenous role in the human brain and therapeutic potentials. Prog. Brain Res. 186, 113-137.

Reddy, D. S., and Kulkarni, S. K. (1998). The role of the GABA$A$ and mitochondrial diazepambinding inhibitor receptors on the effects of neurosteroids on food intake in mice. Psychopharmacology (Berl.) 137, 391-400.

Reddy, D. S., and Kulkarni, S. K. (1999). Sex and estrous cycle-dependent changes in neurosteroid and benzodiazepine effects on food consumption and plus-maze learning behaviors in rats. Pharmacol. Biochem. Behav. 62, 53-60.

Reghunandanan, V., Reghunandanan, R., and Mahajan, K. K. (1998). Arginine vasopressin as a neurotransmitter in brain. Indian J. Exp. Biol. 36, 635-643.

Remage-Healey, L., Maidment, N. T., and Schlinger, B. A. (2008). Forebrain steroid levels fluctuate rapidly during social interactions. Nat. Neurosci. 11, 1327-1334.

Richards, J. G., and Möhler, H. (1984). Benzodiazepine receptors. Neuropharmacology 23, 233-242.

Robel, P., and Baulieu, E. E. (1985). Neurosteroids, $\quad 3 \beta$-hydroxy- $\Delta 5$ derivatives in the rodent brain. Neurochem. Int. 7, 953-958.

Robel, P., and Baulieu, E. E. (1994). Neurosteroids: biosynthesis and function. Trends Endocrinol. Metab. 5 , 1-8.

Robel, P., Schumacher, M., and Baulieu, E. E. (1999). "Neurosteroids: from definition and biochemistry to physiopathologic function," in Contemporary Endocrinology, eds E. E. Baulieu, P. Robel, and M. Schumacher (Totowa: Humana Press), 1-26.

Robel, P., Young, J., Corpéchot, C., Mayo, W., Perche, F., Haug, M., Simon, H., and Baulieu, E. E. (1995). Biosynthesis and assay of neurosteroids in rats and mice: functional correlates. J. Steroid Biochem. Mol. Biol. 53, 355-360.

Roberts, E. (1986). “Guides through the labyrinth of $\mathrm{AD}$ : dehydroepiandrosterone, potassium channels and the C4 component of complement," in Treatment Development Strategies for Alzheimer's Disease eds T. Crook, R. T. Bartus, S. Ferris, and S. Gershon (Madison, CT: Prowley), 173-219.

Rose, T. M., Schultz, E. R., and Todaro, G. J. (1992). Molecular cloning of the gene for the yeast homolog (ACB) of diazepam binding inhibitor/endozepine/acyl-CoAbinding protein. Proc. Natl. Acad. Sci. U.S.A. 89, 11287-11291.

Rupprecht, R. (1997). The neuropsychopharmacological potential of neuroactive steroids. J. Psychiatr. Res. 31, 297-314.

Rupprecht, R., di Michele, F., Hermann, B., Ströhle, A., Lancel, M., Romeo, E., and Holsboer, F. (2001). Neuroactive steroids: molecular mechanisms of action and implications for neuropsychopharmacology. Brain Res. Rev. 37, 59-67.

Rupprecht, R., and Holsboer, F. (1999). Neuroactive steroids: mechanisms of action and neuropsychopharmacological perspectives. Trends Neurosci. 22, 410-416.

Rupprecht, R., and Holsboer, F. (2001). Neuroactive steroids in neuropsychopharmacology. Int. Rev. Neurobiol. 46, 461-477.

Sakaue, M., Saito, N., Taniguchi, H., Baba, S., and Tanaka, C. (1988). Immunohistochemical localization of $\gamma$-aminobutyric acid in the rat pituitary gland and related hypothalamic regions. Brain Res. 446, 343-353.

Sayeed, I., Guo, Q., Hoffman, S. W., and Stein, D. G. (2006). Allopregnanolone, a progesterone metabolite, is more effective than progesterone in reducing cortical infarct volume after transient middle cerebral artery occlusion. Ann. Emerg. Med. 47, 381-389.

Schiess, A. R., and Partridge, L. D. (2005). Pregnenolone sulfate acts through a G-protein-coupled sigmal-like receptor to enhance short term facilitation in adult hippocampal neurons. Eur. J. Pharmacol. 25, 22-29.

Schlinger, B. A., and Remage-Healey, L. (2011). Neurosteroidogenesis: insights from studies of songbirds. J. Neuroendocrinol. 24, 16-21.

Schumacher, M., Akwa, Y., Guennoun, R., Robert, F., Labombarda, F., Desarnaud, F., Robel, P., De Nicola, A. F., and Baulieu, E. E. (2000). Steroid synthesis and metabolism in the nervous system: trophic and protective effects. J. Neurocytol. 29, 307-326.

Schumacher, M., Weill-Engerer, S., Liere, P., Robert, F., Franklin, R. J., Garcia-Segura, L. M., Lambert, J. J., Mayo, W., Melcangi, R. C., Parducz, A., Suter, U., Carelli, C., Baulieu, E. E., and Akwa, Y. (2003). Steroid hormones and neurosteroids in normal and pathological aging of the nervous system. Prog. Neurobiol. 71, 3-29. 
Shannon, E. E., Purdy, R. H., and Grant, K. A. (2005a). Discriminative stimulus effects of $5.6 \mathrm{mg} / \mathrm{kg}$ pregnanolone in DBA/2J and C57BL/6J inbred mice. Alcohol 37, 35-45.

Shannon, E. E., Porcu, P., Purdy, R. H., and Grant, K. A. (2005b). Characterization of the discriminative stimulus effects of the neuroactive steroid pregnanolone in DBA/2J and C57BL/6J inbred mice. J. Pharmacol. Exp. Ther. 314, 675-685.

Shimada, M., Yoshinari, K., Tanabe, E., Shimakawa, E., Kobashi, M., Nagata, K., and Yamazoe, Y. (2001). Identification of ST2A1 as a rat brain neurosteroid sulfotransferase mRNA. Brain Res. 920, 222-225.

Shimizu, C., Fuda, H., Yanai, H., and Strott, C. A. (2003). Conservation of the hydroxysteroid sulfotransferase SULT2B1 gene structure in the mouse: pre- and postnatal expression, kinetic analysis of isoforms, and comparison with prototypical SULT2A1. Endocrinology 144, 1186-1193.

Slobodyansky, E., Guidotti, A., Wambebe, C., Berkovich, A., and Costa, E. (1989). Isolation and characterization of a triakontatetraneuropeptide (TTN) a posttranslational product of diazepam binding inhibitor: specific action at the Ro5-4864 recognition sites. J. Neurochem. 53, 1276-1284.

Slobodyansky, E., Kurriger, G., and Kultas-Llinsky, K. (1992). Diazepam binding inhibitor processing in the rhesus monkey brain: an immunocytochemical study. J. Chem. Neuroanat. 5, 169-180.

Steffensen, S. C., Jones, M. D., Hales, K., and Allison, D. W. (2006). Dehydroepiandrosterone sulfate and estrone sulfate reduce GABA-recurrent inhibition in the hippocampus via muscarinic acetylcholine receptors. Hippocampus 16, 1080-1090.

Stein, D. G. (2001). Brain damage, sex hormones and recovery: a new role for progesterone and estrogen? Trends Neurosci. 24, 386-391.

Strott, C. A. (2002). Sulfonation and molecular action. Endocr. Rev. 23, 703-732.

Strous, R. D., Maayan, R., Lapidus, R., Stryjer, R., Lustig, M., Kotler, M., and Weizman, A. (2003). Value of dehydroepiandrosterone (DHEA) augmentation in the management of negative symptoms in schizophrenia. Arch. Gen. Psychiatry 60, 133-141.

Strous, R. D., Maayan, R., and Weizman, A. (2006). The relevance of neurosteroids to clinical psychiatry: from the laboratory to the bedside. Eur. Neuropsychopharmacol. 16, 155-169.

Sunderland, T., Merril, C. R., Harrington, M. G., Lawlor, B. A., Molchan, S. E., Martinez, R., and Murphy, D. L. (1989). Reduced plasma dehydroepiandrosterone concentrations in Alzheimer's disease. Lancet 2, 570 .

Svec, F., and Porter, J. (1996). Effect of DHEA on macronutrient selection by Zucker rats. Physiol. Behav. 59, 721-727.

Svec, F., and Porter, J. (1998a). Dehydroepiandrosterone: a nutritional supplement with actions in the central nervous system. Nutr. Neurosci. 1, 9-19.

Svec, F., and Porter, J. (1998b). The actions of exogenous dehydroepiandrosterone in experimental animals and humans. Proc. Soc. Exp. Biol. Med. 218, 174-191.

Svec, F., Richards, R. J., and Porter, J. R. (1998). Investigating the debate: does DHEA alter food intake? Nutr. Neurosci. 1, 93-101.

Takase, M., Ukena, K., Yamazaki, T., Kominami, S., and Tsutsui, K. (1999). Pregnenolone, pregnenolone sulfate, and cytochrome P450 side-chain cleavage enzyme in the amphibian brain and their seasonal changes. Endocrinology 140, 1936-1944.

Tappaz, M. L., Wassef, M., Oertel, W. H., Paut, L., and Pujol, J. F. (1983). Light- and electron-microscopic immunocytochemistry of glutamic acid decarboxylase (GAD) in the basal hypothalamus: morphological evidence for neuroendocrine $\gamma$-aminobutyrate (GABA). Neuroscience 9, 271-287.

Tasan, R. O., Lin, S., Hetzenauer, A., Singewald, N., Herzog, H., and Sperk, G. (2009). Increased noveltyinduced motor activity and reduced depression-like behavior in neuropeptide Y (NPY)-Y4 receptor knockout mice. Neuroscience 158, 1717-1730.

Tasker, J. G., Di, S., and Malcher-Lopes, R. (2006). Minireview: rapid glucocorticoid signaling via membraneassociated receptors. Endocrinology 147, 5549-5556.

Thompson, R. R., Dickinson, P. S., Rose, J. D., Dakin, K. A., Civiello, G. M., Segerdahl, A., and Bartlett, R. (2008). Pheromones enhance somatosensory processing in newt brains through a vasotocindependent mechanism. Proc. Biol. Sci. 275, 1685-1693.

Thorsell, A. (2010). Brain neuropeptide $\mathrm{Y}$ and corticotropin-releasing hormone in mediating stress and anxiety. Exp. Biol. Med. 235, 1163-1167.

Todaro, G. J., Rose, T. M., and Shoyab, M. (1991). Human DBI (endozepine): relationship to a homologous membrane associated protein (MA-DBI). Neuropharmacology 30, 1373-1380.

Tong, Y., Toranzo, D., and Pelletier, G. (1991). Localization of diazepambinding inhibitor (DBI) mRNA in the rat brain by high resolution in situ hybridization. Neuropeptides 20, 33-40.

Tonon, M. C., Désy, L., Nicolas, P., Vaudry, H., and Pelletier, G. (1990). Immunocytochemical localization of the endogenous benzodiazepine ligand octadecaneuropeptide (ODN) in the rat brain. $\mathrm{Neu}$ ropeptides $15,17-24$.

Tonon, M. C., Leprince, J., Gandolfo, P., Compère, V., Pelletier, G., Malagon, M. M., and Vaudry, H. (2006). "Endozepines," in Handbook of Biologically Active Peptides, ed. A. J. Kastin (New York: Elsevier), 813-819.

Torres, J. M., and Ortega, E. (2003). DHEA, PREG and their sulfate derivatives on plasma and brain after $\mathrm{CRH}$ and ACTH administration. Neurochem. Res. 28, 1187-1191.

Toyoda, F., Hasunuma, I., Yamamoto, K., Yamashita, M., and Kikuyama, S. (2005). Prolactin acts centrally to enhance newt courtship behavior. Gen. Comp. Endocrinol. 141, 172-177.

Toyoda, F., Ito, M., Tanaka, S., and Kikuyama, S. (1993). Hormonal induction of male courtship behavior in the Japanese newt, Cynops pyrrhogaster. Horm. Behav. 27, 511-522.

Tsutsui, K., Haraguchi, S., Matsunaga, M., Koyama, T., Do Rego, J. L., and Vaudry, H. (2010). Identification of $7 \alpha$-hydroxypregnenolone, a novel bioactive amphibian neurosteroid stimulating locomotor activity, and its physiological roles in the regulation of locomotion. Gen. Comp. Endocrinol. 168, 275-279.

Tsutsui, K., Inoue, K., Miyabara, H., Suzuki, S., Ogura, Y., and Tobari, Y. And Haraguchi, S. (2009). Discovery of a novel avian neurosteroid, $7 \alpha$ hydroxypregnenolone, and its role in the regulation of the diurnal rhythm of locomotor activity in Japanese quail. Gen. Comp. Endocrinol. 163, 117-122.

Tsutsui, K., Inoue, K., Miyabara, H., Suzuki, S., Ogura, Y.,and Haraguchi, S. (2008). 7 $\alpha$-Hydroxypregnenolone mediates melatonin action underlying diurnal locomotor rhythms. J. Neurosci. 28, 2158-2167.

Tsutsui, K., Matsunaga, M., Miyabara, H., and Ukena, K. (2006). Neurosteroid biosynthesis in the quail brain: a review. J. Exp. Zoolog. Part A Comp. Exp. Biol. 305, 733-742.

Tsutsui, K., Matsunaga, M., and Ukena, K. (2003). Review: biosynthesis and biological actions of neurosteroids in the avian brain. Avian Poultry Biol. Rev. 14, 63-78.

Tsutsui, K., Ukena, K., Takase, M., Kohchi, C., and Lea, R. W. (1999) Neurosteroid biosynthesis in vertebrate brains. Comp. Biochem. Physiol. C Pharmacol. Toxicol. Endocrinol. 124, 121-129.

Tsutsui, K., and Yamazaki, T. (1995). Avian neurosteroids I. Pregnenolone biosynthesis in the quail brain. Brain Res. 678, 1-9.

Ueno, H., Yamaguchi, H., Mizuta, M., and Nakazato, M. (2008). The role of PYY in feeding regulation. Regul. Pept. 145, 12-16.

Uzunova, V., Ceci, M., Kohler, C., Uzunov, D. P., and Wrynn, A. S. (2003). Region-specific dysregulation of allopregnanolone brain content in the olfactory bulbectomized rat model of depression. Brain Res. 976, 1-8.

Valera, S., Ballivet, M., and Bertrand, D. (1992). Progesterone modulates a neuronal nicotinic acetylcholine receptor. Proc. Natl. Acad. Sci. U.S.A. 89, 9949-9953.

Vallée, M., Mayo, W., Darnaudery, M., Corpéchot, C., Young, J., Koehl, M. Le Moal, M., Baulieu, E. E., Robel, P., and Simon, H. (1997). Neurosteroids: deficient cognitive performance in aged rats depends on low pregnenolone sulfate levels in the hippocampus. Proc. Natl. Acad. Sci. U.S.A. 94, 14865-14870.

Vallée, M., Mayo, W., and Le Moal, M. (2001). Role of pregnenolone, dehydroepiandrosterone and their sulfate esters on learning and memory in cognitive ageing. Brain Res. Rev. 37, 301-312.

van Broekhoven, F., and Verkes, R. J. (2003). Neurosteroids in depression: a review. Psychopharmacology (Berl.) 165, 97-110.

Vaudry, H., Do Rego, J. L., Burel, D., Luu-The, V., Pelletier, G., and Tsutsui, K. (2011). Neurosteroid biosynthesis in the brain of amphibians. Front. Neuroendocr. Sci. 2:79. doi:10.3389/fendo.2011.00079

Viglietti-Panzica, C., Aste, N., Balthazart, J., and Panzica, G. C. (1994). Vasotocinergic innervation of sexually dimorphic medial preoptic nucleus of the male Japanese quail: 
influence of testosterone. Brain Res. 657, 171-184.

von Horsten, S., Exton, N. G., Exton, M. S., Helfritz, F., Nave, H., Ballof, J., Stalp, M., and Pabst, R. (1998). Brain NPY Y1 receptors rapidly mediate the behavioral response to novelty and a compartment-specific modulation of granulocyte function in blood and spleen. Brain Res. 806, 282-286.

Warren, W. S., and Cassone, V. M. (1995). The pineal gland: photoreception and coupling of behavioral, metabolic, and cardiovascular circadian outputs. J. Biol. Rhythms 10, 64-79.

Weaver, Jr. C. E., Marek, P., Park-Chung, M., Tam, S. W., and Farb, D. H. (1997). Neuroprotective activity of a new class of steroidal inhibitors of the N-methyl-D-aspartate receptor. Proc. Natl. Acad. Sci. U.S.A. 94, 10450-10454.

Wehrenberg, W. B., Corder, R., and Gaillard, R. C. (1989). A physiological role for neuropeptide $\mathrm{Y}$ in regulating the estrogen/progesterone induced luteinizing hormone surge in ovariectomized rats. Neuroendocrinology 49, 680-682.
Weill-Engerer, S., David, J. P., Sazdovitch, V., Liere, P., Eychenne, B., Pianos, A., Schumacher, M., Delacourte, A., Baulieu, E. E., and Akwa, Y. (2002). Neurosteroid quantification in human brain regions: comparison between Alzheimer's and nondemented patients. J. Clin. Endocrinol. Metab. 87, 5138-5143.

Wojtal, K., Trojnar, M. K., and Czuczwar, S. J. (2006). Endogenous neuroprotective factors: neurosteroids. Pharmacol. Rep. 58, 335-340.

Woolley, S. C., Sakata, J. T., and Crews, D. (2004). Evolutionary insights into the regulation of courtship behavior in male amphibians and reptiles. Physiol. Behav. 83, 347-360.

Wu, F. S., Gibbs, T. T., and Farb, D. H. (1991). Pregnenolone sulfate: a positive allosteric modulator at the $\mathrm{N}$ methyl-D-aspartate receptor. Mol. Pharmacol. 40, 333-336.

Xilouri, M., and Papazafiri, P. (2006). Anti-apoptotic effects of allopregnanolone on P19 neurons. Eur. J. Neurosci. 23, 43-54.

Yanagibashi, K., Ohno, Y., Nakamichi, N., Matsui, T., Hayashida, K., Takamura, M., Yamada, K., Tou,
S., and Kawamura, M. (1989). Peripheral-type benzodiazepine receptors are involved in the regulation of cholesterol side chain cleavage in adrenocortical mitochondria. J. Biochem. 106, 1026-1029.

Yanase, H., Shimizu, H., Yamada, K., and Iwanaga, T. (2002). Cellular localization of the diazepam binding inhibitor in glial cells with special reference to its coexistence with brain-type fatty acid binding protein. Arch. Histol. Cytol. 65, 27-36.

Young, L. T. (2002). Neuroprotective effects of antidepressant and mood stabilizing drugs. J. Psychiatry Neurosci. 27, 8-9.

Zheng, P. (2009). Neuroactive steroid regulation of neurotransmitter release in the CNS: action, mechanism and possible significance. Prog. Neurobiol. 89, 134-152.

Zwain, I. H., Arroyo, A., Amato, P., and Yen, S. S. (2002). A role for hypothalamic astrocytes in dehydroepiandrosterone and estradiol regulation of gonadotropinreleasing hormone $(\mathrm{GnRH})$ release by GnRH neurons. Neuroendocrinology 75, 375-383.
Conflict of Interest Statement: The authors declare that the research was conducted in the absence of any commercial or financial relationships that could be construed as a potential conflict of interest.

Received: 31 October 2011; paper pending published: 06 December 2011; accepted: 05 January 2012; published online: 24 January 2012.

Citation: Do Rego JL, Seong JY, Burel $D$, Leprince J, Vaudry D, Luu-The V, Tonon M-C, Tsutsui K, Pelletier G and Vaudry H (2012) Regulation of neurosteroid biosynthesis by neurotransmitters and neuropeptides. Front. Endocrin. 3:4 doi: 10.3389/fendo.2012.00004

This article was submitted to Frontiers in Neuroendocrine Science, a specialty of Frontiers in Endocrinology.

Copyright (ㄷ) 2012 Do Rego, Seong, Burel, Leprince, Vaudry, Luu-The, Tonon, Tsutsui, Pelletier and Vaudry. This is an open-access article distributed under the terms of the Creative Commons Attribution Non Commercial License, which permits non-commercial use, distribution, and reproduction in other forums, provided the original authors and source are credited. 